\title{
National Framework for Personal Protective Equipment Conformity Assessment - Infrastructure
}


This page intentionally left blank. 


\section{National Framework for Personal Protective Equipment Conformity Assessment - I nfrastructure}

DEPARTMENT OF HEALTH AND HUMAN SERVICES

Centers for Disease Control and Prevention

National Institute for Occupational Safety and Health 
This document is in the public domain and may be freely copied or reprinted.

\section{Disclaimer}

This Framework is intended exclusively as recommendations and to serve informational purposes, and does not create any legal obligations or regulatory requirements.

Mention of any company or product does not constitute endorsement by the National Institute for Occupational Safety and Health (NIOSH) or the National Institute of Standards and Technology (NIST). In addition, citations to websites external to NIOSH or NIST do not constitute NIOSH or NIST endorsement of the sponsoring organizations or their programs or products. Furthermore, NIOSH and NIST are not responsible for the content of these websites. All web addresses referenced in this document were accessible as of the publication date.

\section{Ordering I nformation}

To receive documents or other information about occupational safety and health topics, contact NIOSH:

Telephone: 1- 800- CDC- I NFO (1-800-232-4636)

TTY: $1-888-232-6348$

CDC INFO: www.cdc.gov/info

or visit the NIOSH website at www.cdc.gov/ niosh.

For a monthly update on news at NIOSH, subscribe to NIOSH eNews by visiting www.cdc.gov/ niosh/ eNews.

\section{Suggested Citation}

NIOSH [2017]. National framework for personal protective equipment conformity assessment - infrastructure. By D'Alessandro M. Pittsburgh, PA: U.S. Department of Health and Human Services, Centers for Disease Control and Prevention, National Institute for Occupational Safety and Health, DHHS (NIOSH) Publication 2018-102.

Lisa Carnahan, U.S. Department of Commerce, National Institute of Standards and Technology

Richard Metzler, Richard W. Metzler, Inc.

J oshua Scott, Colorado School of Public Health | CU Anschutz Medical Campus Mountain \& Plains ERC

DHHS (NIOSH) Publication No. 2018-102

\section{November 2017}




\section{TABLE OF CONTENTS}

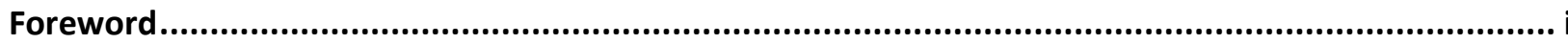

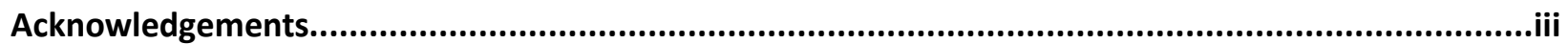

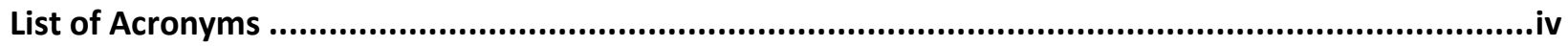

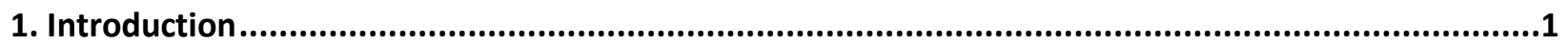

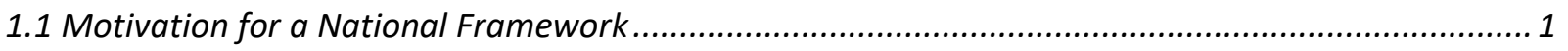

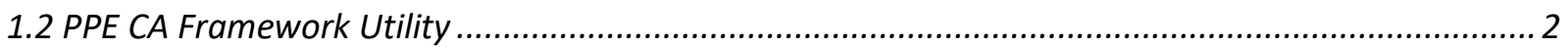

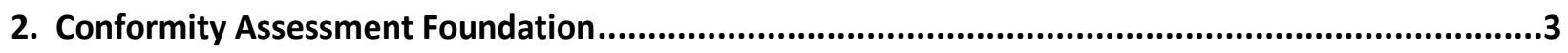

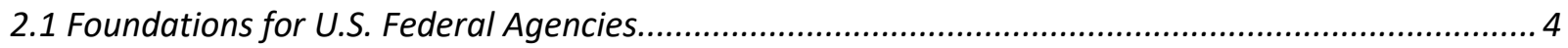

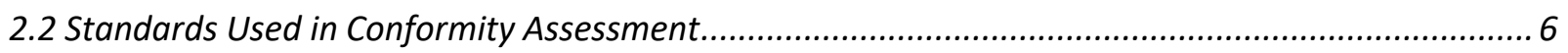

2.3 Current PPE Conformity Assessment Programs in the United States............................................ 6

3. CA Framework and Recommendations for Implementation ......................................................6

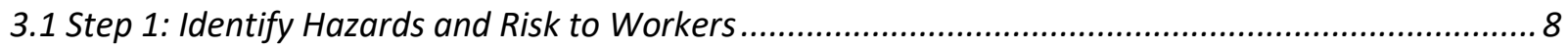

3.2 Step 2: Identify PPE Types Needed to Address Hazards............................................................... 9

3.3 Step 3: Identify and Select Standards That Address Hazards........................................................ 9

3.4 Step 4: Define the CA Requirements and Activities in Consideration of Risks to Workers................ 10

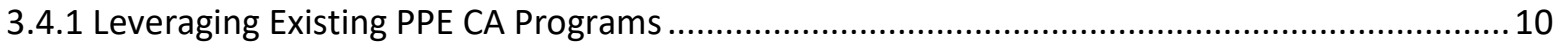

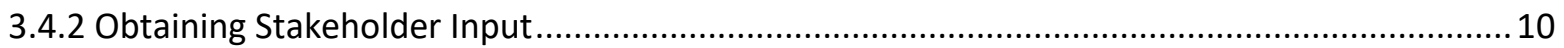

3.4.3 Understanding CA Program Owner Responsibilities .............................................................. 11

3.4.4 Analyzing the Risk of Injury and Illness Associated with Non-conformity .............................. 12

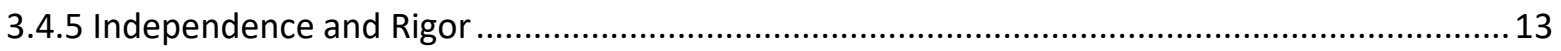

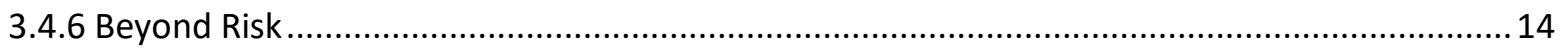

3.4.7 Connecting Levels of Risk and Appropriate CA Activities ................................................... 14

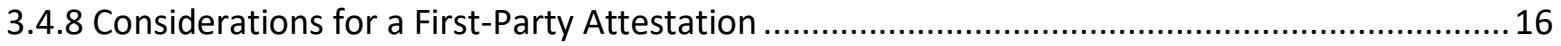

3.4.9 Considerations for Third-Party Use and Attestation........................................................... 17

3.4.10 Labels, Product Lists, and Other Documentation of Conformity .......................................... 18

3.4.11 Design Market Surveillance Strategies ............................................................................. 18

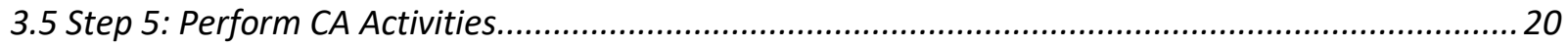

3.5.1 Conformity Assessment Improvement Activities................................................................. 20

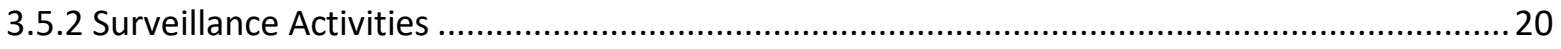

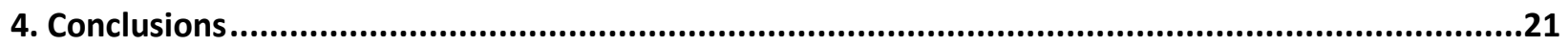

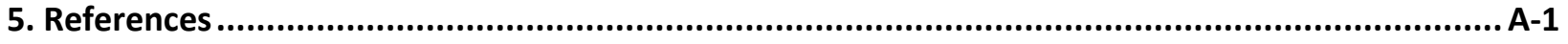

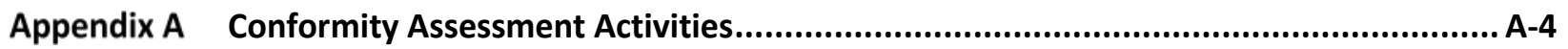

Appendix B Standards for Conformity Assessment Activities ...................................................... B-1

Appendix C Sample Conformity Assessment Programs ................................................................ C-1

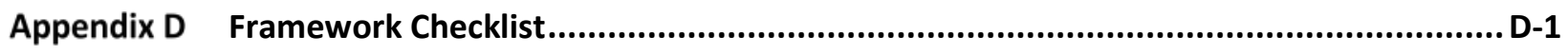




\section{Figures}

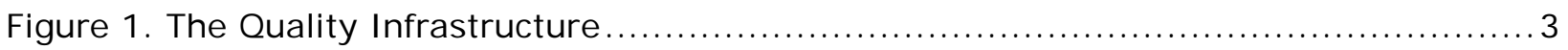

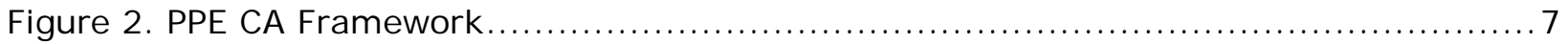

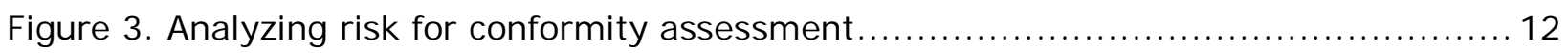

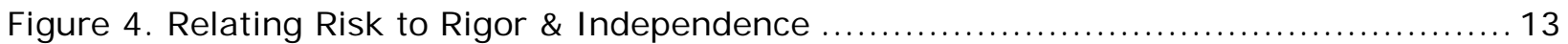

Figure 5. Post Market Surveillance Action [Adapted from PROSAFE: 2009, Fig 26] ........... 19

Figure A-1. Functional Approach to Conformity Assessment ..............................

\section{Tables}

Table-1 Conformity Assessment Activities Based on Risk Category $\ldots \ldots \ldots \ldots \ldots \ldots \ldots \ldots \ldots \ldots$

Table B-1 ISO Standards and Conformity Assessment..................................

Table B-2 ISO/IEC Conformity Assessment Standards ...................................

Table B-3 ISO/IEC 17067 Example Certification Programs ................................ B-4

Table C-1 Sample PPE Conformity Assessment Programs in the United States................ C-1

Table D-1 Checklist for Application of PPE Conformity Assessment Framework ............. D-1 
The goal of our efforts at the National Institute for Occupational Safety and Health (NIOSH) is to provide national and world leadership to prevent workplace illnesses and injuries. We accomplish this by conducting and supporting activities to protect workers from workrelated exposures to hazards. One core objective of this approach involves the development and use of personal protective equipment (PPE).

Workers are more likely to appropriately use PPE when they are confident that the equipment will provide the intended protections based on its conformance with appropriate standards. The National Academies of Sciences, Engineering, and Medicine (the Academies) indicates that "for the consumer or worker, conformity assessment provides confidence in the claims made about the product by the manufacturer and may assist the consumer with purchasing decisions in determining the fitness of a product for it its intended use." [IOM, 2011, page 3] A comprehensive and tailor-made conformity assessment (CA) program is the most effective way to manage risks of a non-conforming PPE and instill this confidence in PPE users.

Following recommendations from the Academies, we have defined a Framework to assist in developing, structuring, and managing PPE CA for American workplaces.

This Framework is the product of collaboration among the NIOSH representatives and a broad cross-section of members of the PPE community. This group's multi-year effort; (1) identified and analyzed national and international conformity assessment programs and requirements, (2) investigated injury and enforcement surveillance databases, (3) researched and gathered PPE standards, and (4) developed a risk-based approach to conformity assessment resulting in this Framework.

The Framework was informed by a comprehensive review of good practice criteria derived from current CA programs and is based on national and international standards published by the International Organization for Standardization and International Electrotechnical Commission (ISO/IEC) (e.g., ISO/IEC 17065, 17025). These standards, which serve as the basis for CA requirements in many programs worldwide, help U.S. suppliers meet international requirements for evidence of conformity.

The recommendations in this document are intended to serve as foundational principles for various types of conformity assessment programs for occupational PPE. They are not requirements for how these programs must, or will, function. Conformity assessment activities should be tailored to the needs of product users, suppliers, and regulatory authorities. They should result in products that protect workers who rely on PPE; facilitate trade, fair competition, and market access; be cost-effective; and provide assurance of conformance.

We developed the Framework in a way that it can be appropriately tailored and broadly applied to all PPE that protects from a variety of risks regardless of the hazard, type, or environment. For example, the conformity assessment program for firefighter boots would 
look different than the conformity assessment program for steel toe boots for construction workers. The Framework describes the foundational principles of CA to enable program owners and operators to define the level of independence and rigor based on risk to workers.

The Framework defines a process that contains five steps that link the elements of the welldeveloped public health hierarchy of controls with those of CA. The Framework is supported by a checklist assisting prospective CA program owners to evaluate and then define an approach specific to workplace needs. This document represents the first in a series of documents supporting the National Framework for Conformity Assessment of PPE. NIOSH will use this document series to publish additional documents related to the development, implementation and use of conformity assessment programs for PPE.

To support the Framework and facilitate its use NIOSH will continue to:

1. Provide impartial research leadership to define and fill scientific gaps;

2. Lead the development and incorporation of scientific input into PPE standards;

3. Support a sustainable U.S. PPE CA infrastructure by providing national leadership;

4. Establish a PPE clearinghouse to support national occupational safety and health; and

5. Develop and publish additional documents to support implementation of the framework. 
This report was prepared by the NIOSH, National Personal Protective Technology Laboratory (NPPTL) to address the Institute of Medicine (IOM) ${ }^{1}$ and National Research Council (NRC) recommendations regarding the need for national risk-based conformity assessment (CA) activities for personal protective equipment (PPE). NIOSH is appreciative of the following current and former NIOSH employees, and stakeholders who actively contributed to the study of national and international CA programs and requirements, investigated injury and enforcement surveillance databases, researched and gathered PPE standards in support of the PPE CA Working Group (PCAWG) [NIOSH Docket 237-A] ${ }^{2}$, or provided information used by NIOSH to formulate this national Framework.

- 3M Company, Occupational Health

- Adso Enterprises, Inc.

- AFL-CIO, Department of Occupational Safety and Health

- Association of Occupational Health Professionals in Healthcare

- American Association for Laboratory Accreditation

- American National Standards Institute

- ASTM International

- DuPont Protective Technologies

- Emergint Technologies, Inc.

- Gateway Safety

- ICS Laboratories, Inc.

- Institute of Medicine, Committee on Personal Protective Equipment

- International Association of Fire Fighters

- International Safety Equipment Association

- International Personnel Protection, Inc.

- J.P. Zeigler Co., LLC

- JSJ and Associates

- Kimberly Clark Professional

- Mine Safety and Health Administration

- National Institute of Standards and Technology

- National Fire Protection Association

- National Safety Council, International \& Environmental Health and Safety

- JSJ and Associates

- Kimberly Clark Professional

- Mine Safety and Health Administration

- National Institute of Standards and Technology

- National Fire Protection Association

- National Safety Council, International \& Environmental Health and Safety
- Occupational Safety and Health Administration

- Raytheon Company

- Richard W. Metzler, Inc.

- RTI International

- Safety Equipment Institute

- Scott Safety

- Syntech, International

- CPWR - The Center for Construction Research and Training

- University of Maryland - School of Medicine

- University of Maryland - Eastern Shore

- University of Pittsburgh

- University of Wisconsin

- Underwriters Laboratories

- United States Coast Guard

- URS Corporation

- Current and former NIOSH employees Bryan Beamer Roland Berry Ann David Book Christopher Coffey

Judi Coyne Brent Doney William Haskell Jackie Krah William Newcomb Charles Oke Jay Parker John Perrotte Lynn Rethi Teresa Seitz Ronald Shaffer John Sporrer Jonathan Szalajda

${ }^{1}$ On March 15, 2016 the Institute of Medicine was renamed the Health and Medicine Division (HMD) of the National Academies of Sciences, Engineering, and Medicine (the Academies). 


\section{LIST OF ACRONYMS}

ACUS

ANSI

CA

CASCO

CFR

FIT

IEC

IOM

NFPA

NIJ

NIJ CTP

$\mathrm{NIOSH}$

NIST

NPPTL

NRC

NTTAA

OMB

OSHA

PCAWG

PPE

PPT

SDoC

SDO

USCG

WTO
Administrative Conference of the U.S.

American National Standards Institute

Conformity Assessment

ISO Committee on Conformity Assessment

Code of Federal Regulations

Follow-up Inspection and Testing

International Electrotechnical Commission

Institute of Medicine now the Health and Medicine Division (HMD)

National Fire Protection Association

National Institute of J ustice

National Institute of J ustice Compliance Testing Program

National Institute for Occupational Safety and Health

National Institute of Standards and Technology

National Personal Protective Technology Laboratory

National Research Council

National Technology Transfer and Advancement Act

Office of Management and Budget

Occupational Safety and Health Administration

PPE Conformity Assessment Working Group

Personal Protective Equipment

Personal Protective Technologies

Supplier's Declaration of Conformity

Standards Development Organization

United States Coast Guard

World Trade Organization 


\section{I ntroduction}

Conformity assessment (CA) is the demonstration that a product meets specified requirements. "Conformity assessment can verify that a particular product meets a given level of quality or safety. It can provide explicit or implicit information about the product's characteristics, the consistency of those characteristics and/or the performance of the product. Conformity assessment can also increase a buyer's confidence in a product, furnish useful information to a buyer, and help to substantiate advertising and labeling claims. Information on conformance (or non-conformance) to a particular standard can provide an efficient method of conveying information needed by regulators or buyers on the product's safety and suitability" [ANSI 2014a, page 3]. CA is the vital link between product requirements and the products themselves. Although the Occupational Safety and Health Administration (OSHA) and other agencies publish guidance for effective worker protection using PPE, there is currently no single regulatory body, official guidance, or mandating authority for the CA of all PPE. In the absence of national policy and guidance, NIOSH has developed the Framework to provide a risk-based, evidence-driven PPE CA approach for occupational use PPE.

\subsection{Motivation for a National Framework}

When PPE is used to protect the health and safety of workers, those workers must have confidence that the product they are using conforms to applicable standards. A comprehensive, tailored CA program is the most effective way to instill this confidence in PPE users. Assurances that products provide the expected protection may be determined by following a rigorous conformity assessment process using relevant technical standards and metrics.

In 2008, the Institute of Medicine (IOM) and National Research Council (NRC) issued a report on the NIOSH Personal Protective Technology (PPT) Program. In that report a recommendation was made for the NIOSH to "Implement and Sustain a Comprehensive National Personal Protective Technology Program." Regarding overseeing PPT certification, the National Program should also "collaborate with other relevant government agencies, private sector organizations, and not-for-profit organizations to conduct an assessment of the certification mechanisms needed to ensure the efficacy of all types of PPT" [IOM and NRC, 2008, page 117].

A follow-up study published in 2011 by the IOM elaborated on the 2008 report by recommending that NIOSH "Develop and Implement Risk-Based Conformity Assessment Processes for Non-Respirator PPT" and NPPTL "should serve in a leadership role and convene other relevant government agencies, certifying and accrediting organizations, manufacturers, and end users to develop and implement a comprehensive, tiered risk based framework for the classification and conformity assessment of PPT products for specific applications." The IOM emphasized that "This framework should be based on the degree of risk to the safety and health of the user and other factors affecting the feasibility of implementing the proposed conformity assessment processes." [IOM, 2011, page 9]. In addition to health and safety risks, the framework is to take into account "[...] economic and other pragmatic factors (e.g., cost of conformance, impediments to innovation, risk to 
manufacturer's reputation due to poor product quality and/or product failure)" [IOM, 2011, page 7].

In response to these recommendations, NIOSH formed the PPE CA Working Group (PCAWG) comprised of representatives from more than 30 public and private organizations. The group developed a comprehensive evaluation of conformity assessment and subsequent work products which are available in NIOSH Docket 237-A [NIOSH Docket 237-A] that served as input to the development of this Framework.

The Framework is intended to help the PPE industry meet the need for "a consistent riskbased approach to PPE CA" as highlighted in the IOM 2011 report. It supports CA programs to effectively demonstrate and attest that a PPE product conforms to the performance, quality, reliability, and other standards that are selected to meet health and safety needs for reducing the wearer's exposure to workplace hazards to acceptable levels.

\subsection{PPE CA Framework Utility}

The Framework is based on good practice criteria derived from international CA standards and practices, current U.S. legal and regulatory requirements, and evidence from existing CA activities in the United States and other industrialized economies. [NIOSH Docket 237-A] The CA concepts on which the Framework is based are identified in Appendix A.

An approach for developing, structuring, and managing PPE CA in the U.S. is provided and can be tailored and applied to all PPE that protects from a variety of occupational risks regardless of the hazard, type, or environment. The Framework describes the foundational principles of CA to enable CA program developers and operators to stratify the level of independence and rigor based on likely risk to workers.

The Framework elements are not regulatory requirements for a CA program. The elements may be used to improve existing programs, develop new programs, and provide information to those interested in the concept of conformity assessment.

Both public agencies and private organizations operate PPE CA programs in the U.S. The programs vary along a continuum of rigor in requirements and testing as well as independence from the PPE supplier.

The Framework is intended to serve all organizations that are or may become owners of CA programs. These foundational CA principles provide support for effectively demonstrating that a PPE product conforms to selected standards. CA activities should be tailored to the needs of product users, suppliers, and regulatory authorities. They should result in products that protect workers who rely on PPE; facilitate trade, fair competition, and market access; be cost-effective; and provide regulatory confidence.

The Framework draws upon federal policy and administrative guidance as well as current national public and private CA programs. It aims to facilitate commerce by incorporating existing CA infrastructure in the U.S. and recommending practices that link hazards to protection requirements in PPE standards. In addition, it suggests appropriate CA activities based upon the risk to workers associated with a non-conforming PPE. 
Docket 237-A contains resources developed from the multi-year effort of the PCAWG which led to the development of the Framework.

Personal protective technologies (PPT) such as instrumentation and sampling devices are not included in the Framework for PPE; however, the Framework may be applied to address conformity of PPT in the future.

\section{Conformity Assessment Foundation}

CA is defined as "demonstration that specified requirements relating to a product, process, system, person, or body are fulfilled." [ISO/IEC 17000] The standard also describes the interrelationships of CA procedures. CA procedures evaluate whether the products, services, or systems produced or operated have the required characteristics and whether these characteristics are consistent from product to product, service to service, or system to system. CA includes sampling and testing, inspection, supplier's declaration, certification, and quality and environmental system assessment and registration. It also includes accreditation of the competence of the provider of those activities by a third party and recognition of an accreditation program's capability. CA processes and activities are described in Appendix A.

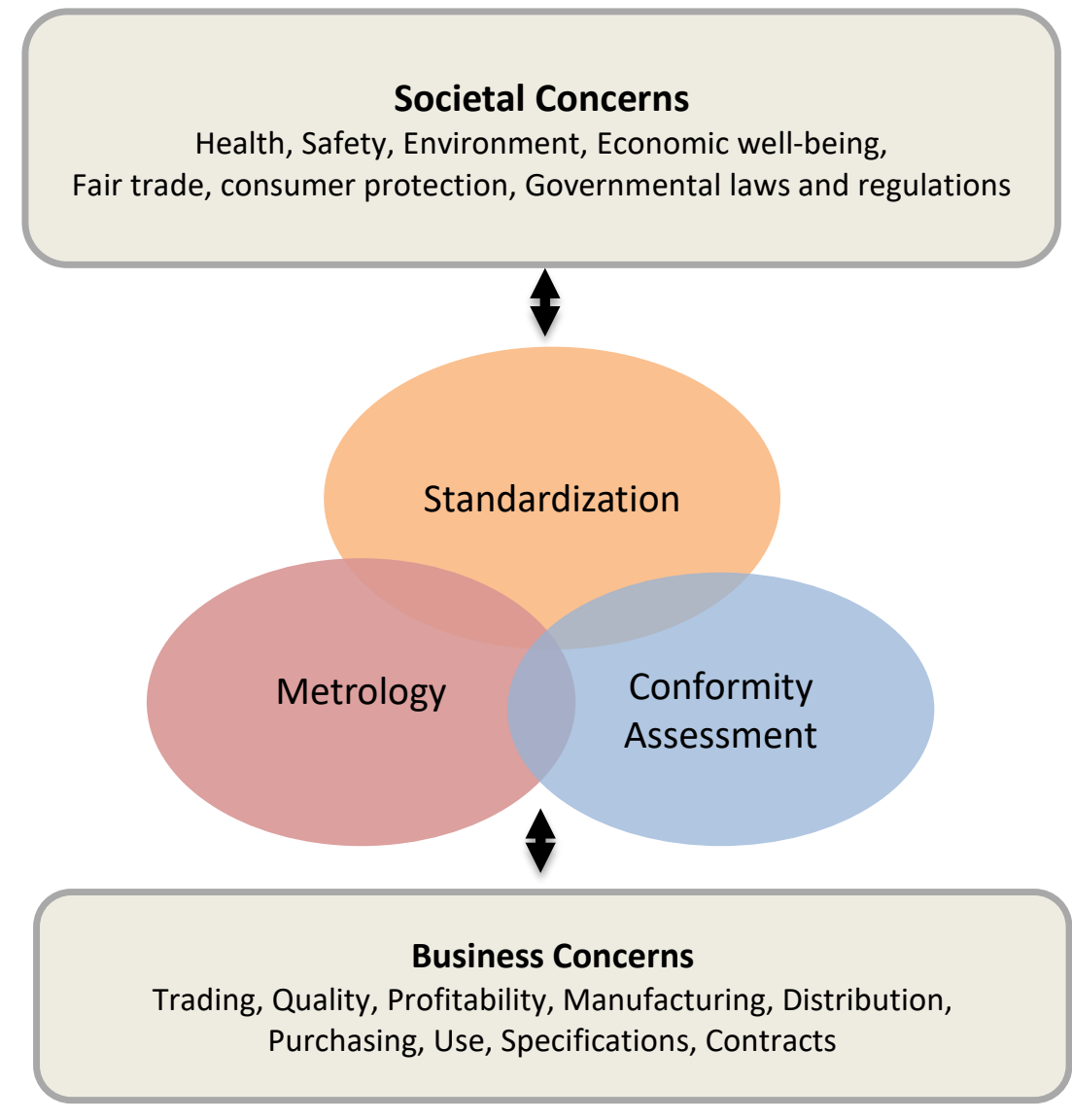

CA is one of the three interdependent pillars of a quality infrastructure (see Figure $\mathbf{1}$ ). Together with metrology and standardization (i.e., the development and use of technical standards), CA is an efficient means to achieve public health and safety goals and to remove barriers to commerce and trade.

Consumers benefit from CA because it gives them a basis for selecting products and for having confidence that their health and safety requirements are met. Conforming products are directly related to health and safety requirements through standards used in the CA processes. Suppliers and service providers benefit both by avoiding the costs of product failures in the market and by obtaining access to internal and external markets.

The basic building block of CA is a program that relates to a particular group of products with "sufficiently similar characteristics that the same set of rules and procedures can be carried out under the same management for assessing conformity with the same set of 
specified requirements" [ISO, 2010:47]. A program consists of rules, procedures, and management requirements related to assessing conformity with a particular set of specified requirements. In the international conformity assessment community the term CA scheme is used rather than CA program. Per ISO/IEC 17000, the terms CA scheme and CA program are synonymous.

Each CA program should have an owner. The program owner can be any type of organization - public or private. Common types of organizations are government or regulatory bodies, non-governmental organizations, trade or manufacturing associations, product certification bodies or groups of certification bodies, and consumer organizations. [ISO/IEC 17067: 2013[E]].

Many types of organizations can perform CA activities including: (1) a first party, which is generally the manufacturer or other supplier; (2) a second party, which is generally the purchaser or user of the product; or (3) a third party, which is an independent entity that is generally distinct from the first or second party and has no interest in transactions between the first and second parties.

Terminology for CA processes is found in standard ISO/IEC 17000. Additional terminology common to PPE CA can be found in NIOSH Docket 237-A.

\subsection{Foundations for U.S. Federal Agencies}

The Framework is informed in part by federal law, regulatory policy, and administrative guidance. The National Technology Transfer and Advancement Act (NTTAA) (Public Law 104-113) requires all U.S. federal agencies to use voluntary consensus standards to the extent possible [IOM, 2011:26-27]. The Office of Management and Budget (OMB) Circular A-119, Revised, "Federal Participation in the Development and Use of Voluntary Consensus Standards and in Conformity Assessment Activities" establishes policies on federal use and development of voluntary consensus standards and on CA activities.

The Agreement on Technical Barriers to Trade (TBT), one of the agreements within the World Trade Organization (WTO) and to which the U.S. is a signatory, prohibits the signatories from having CA procedures that are more trade restrictive than necessary to meet their legitimate regulatory objectives. To comply with these agreements WTO members should

- ensure that the results of another member's CA procedures based on equivalent procedures are accepted, even when they differ from their own,

- follow strict transparency provisions to enable members to understand and have an opportunity to influence another member's proposed CA practices that could affect international trade, and

- support global harmonization of CA procedures.

The NTTAA directs the U.S. National Institute of Standards and Technology (NIST) to coordinate CA activities of federal, state, and local entities with private sector technical standards activities and CA activities to eliminate any unnecessary duplication of CA 
activities [NIST: 2012]. NIST has published guidance outlining federal agencies' considerations for evaluating the efficiency and effectiveness of their CA activities. NIST guidance is intended to help federal agencies improve the management and coordination of their own CA activities in support of their regulatory, procurement, and other mission objectives [NIST: 2012]. NIST makes specific recommendations to:

- provide a rationale for use of specified CA procedures and processes,

- use the results of other governmental agency and private sector organization CA practices, programs, and activities,

- use relevant guides or standards for CA practices published by domestic and international standardizing bodies to enhance the safety and efficacy of proposed new CA requirements and measures,

- participate in efforts designed to be cost-effective and reduce industry burden:

- improve coordination among governmental and private sector CA activities,

- avoid unnecessary duplication and complexity in federal CA activities,

- harmonize federal requirements for quality and environmental management systems for use in procurement and regulation,

- establish criteria for the development and implementation of governmental recognition systems to meet government recognition requirements imposed by other nations and regional groups in support of the efforts of the U.S. government to facilitate international market access for U.S. products, and - develop national infrastructures for coordinating and harmonizing U.S. CA needs, practices, and requirements.

- encourage domestic and international recognition of U.S. CA results by supporting the work of the U.S. government in international trade and related negotiations with foreign countries and U.S. industry in pursuing agreements with foreign national and international private sector organizations.

Recommendation 2012-7 of the Administrative Conference of the U.S. (ACUS) sets forth guidance for federal agencies when deciding whether to develop a third-party program to specifically assess regulatory compliance. ACUS makes these recommendations:

- consult governmental and nongovernmental resources relating to third-party CA;

- compare a third-party approach with direct governmental assessment of compliance related to effectiveness, costs, efficiency and timeliness, and agency capacity;

- evaluate whether sufficient incentives exist or can be created to attract the participation of regulated entities in the third-party program;

- design its CA program to be proportional to the risks associated with regulatory noncompliance;

- consider relying on existing CA standards, particularly international standards that set forth requirements for CA and accreditation bodies; and consider that existing standards can be supplemented with program specific rules; 
- ensure that both the government and the public have appropriate access to information about program operations to facilitate transparency and agency oversight; and

- set forth how they intend to conduct oversight to ensure that a third-party program is fulfilling its regulatory purpose [ACUS: 2012].

\subsection{Standards Used in Conformity Assessment}

Standards are critical within a CA process. Standards provide the basis for CA activities that, in turn, are the basis for many buyer-seller transactions. Hence, standards used in CA activities can have tremendous impact on companies and nations and even on the economic fabric of the world market.

Standards can cover many aspects of the CA process. They can describe characteristics of the product for which conformity is sought; the methodology (e.g., test, inspection, or other methods) used to assess that conformity; or even the CA process itself (e.g., how a certification program should be operated). With respect to the latter, foremost among these are the CA standards published by the ISO/IEC. A list of these "CASCO Toolbox" standards is provided in Appendix B and shown in Tables B-1 and B-2.

\subsection{Current PPE Conformity Assessment Programs in the United States}

Both public and private sector organizations operate CA programs in the United States. A sample of third-party CA program owners for PPE and the products they cover is listed in Table C-1. These program owners include independent testing/inspection organizations, organizations focused on an industrial group and/or its customers (e.g., National Fire Protection Association [NFPA]), and government agencies implementing a regulatory requirement for conformity. Other common program owners for PPE are second-party industrial buyers or product users. The U.S. Army Program Executive Office (PEO), Soldier, Project Manager, Soldier Protection \& Individual Equipment organization operates a secondparty program to determine conformity to its PPE requirements for protective eyewear and flame resistant combat glove products.

\section{CA Framework and Recommendations for I mplementation}

The purpose of the National Framework for Personal Protective Equipment Conformity Assessment is to establish a set of principles and provide recommendations for CA of PPE products in the United States. This is accomplished by addressing risk of worker exposure to a non-conforming product. The Framework helps advance the PPE industry with meeting the need for "a consistent risk-based approach to PPE CA," which was highlighted by the IOM in its report Certifying Personal Protective Technologies: Improving Worker Safety [IOM, 2011]. The Framework is based on good practice criteria derived from international CA standards and practices, current U.S. legal and regulatory requirements, and evidence from existing $\mathrm{CA}$ activities in the United States and other advanced industrialized economies. [NIOSH Docket 237-A] 
The Framework can be appropriately tailored and universally applied to all PPE that protects from a variety of risks regardless of the hazard, type, or environment. For example, the conformity assessment program for firefighter boots would look different than the conformity assessment program for steel toe boots for construction workers. The Framework describes the foundational principles of CA to enable program owners and operators to define the level of independence and rigor based on risk to workers.

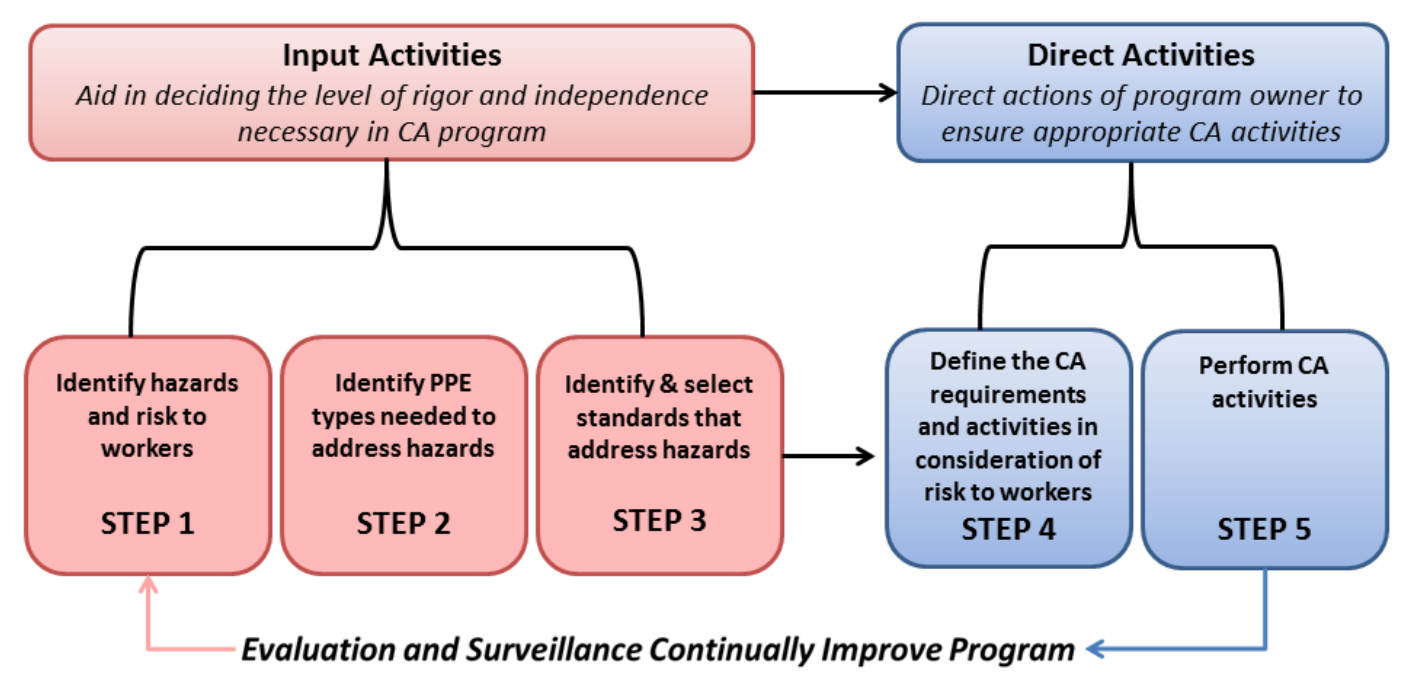

Figure 2. PPE CA Framework

The first three steps in the Framework shown in Figure $\mathbf{2}$ are activities that provide input into CA program decisions and are not necessarily performed by CA owner/operators:

1. Identify hazards and risk to workers;

2. Identify PPE types needed to address hazards; and

3. Identify and select standards that address hazards.

The last two steps are primary activities of CA and should be directly addressed with the authority of the program owner and input from concepts one through three. Details for each of these five steps are provided on the following pages.

4. Define the CA requirements and activities;

5. Perform CA activities.

In addition, it is important to assess the effectiveness of the CA program and conformance of PPE to the requirements of the CA program. Section 7.11, Design Market Surveillance Strategies, and Section 8, Perform CA Activities, provide information for effective evaluation and surveillance activities.

A Framework Checklist (Table D-1 in Appendix D) has been developed for the PPE CA process and represents a compilation of key concepts and considerations for developing and 
operating CA programs. This checklist assists CA program owners who wish to (1) evaluate the Framework for application to their particular circumstances and/or (2) strengthen an existing CA program or (3) develop and implement a program if a decision is made to go forward. As such, a PPE CA program is part of an overall risk management system that NIOSH recommends for ensuring worker safety and health. The Framework may also serve as a useful tool for stakeholders interested in assisting current or potential CA programs in developing a CA program to address PPE conformity.

The questions identified in Table D-1 are intended to help program owners arrive at decisions that ensure that programs are tailored according to the potential risk of a nonconforming products and provide confidence with respect to product conformity to standards. This checklist is meant to assist in the process of developing appropriate CA programs, not the sole means of assuring adequacy. The checklist can be supplemented and tailored to suit the specific organization or need. Along with relevant CA standards and technical guidance, this document can be used to increase confidence that a PPE CA program will perform according to desired outcomes.

The remaining sections provide a description of each of the five Framework steps and specific considerations that aid program owners and operators as they design, develop and operate conformity assessment programs.

\subsection{Step 1: I dentify Hazards and Risk to Workers}

Hazards are widespread in work environments and include: sharp edges, falling objects, flying sparks, chemicals, and noise, among many others. The U.S. Department of Labor Occupational Safety and Health Administration (OSHA) and other regulatory agencies require that employers protect their employees from workplace hazards that can cause injury. In support of those requirements, OSHA publishes guidance for effective worker protection using PPE that includes providing information for performing job hazard analysis [OSHA, 2002].

Controlling a hazard at its source is the best way to protect employees. The most effective control is eliminating the hazard and associated risk (e.g., by eliminating the chemical, machine, task, or work process). If elimination is not practical or sufficient, hazards should be minimized by substituting the hazard with a less hazardous source (e.g., use a less hazardous chemical or use a less noisy machine). Isolating the hazard (e.g., establish barriers to isolate the worker or isolate the hazard) reduces exposure to the hazard. If engineering controls are not practical or do not reduce the hazard to an acceptable level, the next level of control involves administrative controls including safe work practices that is, making changes in the way people work and promoting safe work practices via education and training. For more information on the hierarchy of controls refer to https://www.cdc.gov/niosh/topics/hierarchy.

When engineering controls and administrative controls (including work practices) are not feasible, PPE is recommended. PPE includes clothing and equipment that act to minimize exposure to workplace injuries and illnesses, which may result from contact with a variety of 
workplace hazards [OSHA, 2003]. Examples of PPE include gloves, foot and eye protection, protective hearing devices, hard hats, respirators, and full body suits.

I dentify the physical and health hazards for which workers must use PPE for their protection.

\subsection{Step 2: I dentify PPE Types Needed to Address Hazards}

After the hazards have been identified, PPE types are selected to address the identified hazards. The example below demonstrates the inclusion of the hazard and PPE type addressed by the standard.

\section{EXAMPLE: HAZARD I NFORMATI ON IS I NCORPORATED I NTO STANDARDS}

ASTM F1818-13, Standard Specification for Foot Protection for Chain Saw Users identifies the HAZARDS from which conforming products are intended to protect by stating that "the objective of this specification is to prescribe [...] criteria for footwear and foot protective devices, worn by chain saw operators, which are intended to reduce foot injuries caused by contact with a running power chain saw."

\subsection{Step 3: I dentify and Select Standards That Address Hazards}

Standards connect identified hazards with measurable requirements that, when met, should provide wearers with PPE that reduces the risk of the hazard. The CA program owner (or program developer) should understand whether the requirements contained in the standard are adequate to address the identified hazards. The example presented below demonstrates how identified hazards can be linked to requirements through direct text in a standard [ANSI/ISEA Z89.1, 2014].

\section{EXAMPLE: HAZARD AND PROTECTI ON REQUI REMENTS ARE LI NKED I N STANDARDS}

ANSI/ISEA Z89.1, "This standard establishes minimum performance requirements for protective helmets that reduce the forces of impact and penetration and that may provide protection from electric shock (not arc flash)." The hazard is described as "Type II helmets are intended to reduce the force of impact resulting from a blow to the top or sides of the head" [Section 4.1.2]. The related requirement states "Helmets shall be tested in accordance with Section 10.2 and shall not transmit a force to the test headform that exceeds $4450 \mathrm{~N}$ (1,000 lbf). Additionally, for each preconditioning specified, the maximum transmitted force of individual test samples shall be averaged. The averaged values shall not exceed $3780 \mathrm{~N}$ ( $850 \mathrm{lbf}$ )" [Section 7.1.2].

To help employers, users of PPE, and others determine which PPE standards must be met by their equipment, NIOSH in collaboration with key partners including the International Safety 
Equipment Association, the Occupational Safety and Health Administration, the Mine Safety and Health Administration, and other members of the PPE Conformity Assessment Working Group developed the PPE-INFO database. The database serves as a compilation of federal regulations and consensus standards for respirators and non-respiratory PPE. The standards information was obtained from U.S. government agencies and consensus standards organizations. It is a tool for standards developers, certification organizations, manufacturers, purchasers, end users, safety and health professionals, and researchers.

The information in the database can be used to determine whether a product meets a certain standard and if the performance requirements of that standard provide an appropriate level of protection against expected hazards. This database is currently available at https://wwwn.cdc.gov/ppeinfo.

\subsection{Step 4: Define the CA Requirements and Activities in Consideration of Risks to Workers}

Selecting CA requirements is based on factors such as the risk of injury and illness associated with non-conformity, degree of hazard, current conformity in the market, regulatory requirements, cost, and other factors. Refer to Appendix A, Conformity Assessment Processes and Activities for information on CA processes and activities.

\subsubsection{Leveraging Existing PPE CA Programs}

Leveraging existing conformity assessment programs should be the first consideration made by a CA program owner. Existing PPE CA programs in the U.S. and internationally represent a wide diversity of public and private sector approaches including declarations of conformance from supplier (self-declarations) to independent third-party certification. Current CA programs in the U.S. operated by public agencies or private sector organizations are primarily for products that protect workers against medium to high hazards (e.g., respiratory protection, body armor, and personal flotation devices). Certification programs for PPE are conducted by private sector bodies (e.g., Safety Equipment Institute, Underwriters Laboratories); and federal agencies such as NIOSH (e.g., respiratory protective devices), National Institute of J ustice (NIJ) (e.g., body armor), United States Coast Guard (USCG) (e.g., personal flotation devices), and the Food and Drug Administration (FDA) (e.g., medical devices). Program owners should proceed with designing a PPE CA program if existing CA programs are not suitable.

\subsubsection{Obtaining Stakeholder I nput}

Whether the program is public, private, or a combination of both, the specific content of the CA program should be agreed upon among the key stakeholders [ISO/IEC 17067, 2013[E]]. Relevant stakeholders of PPE programs are workers and their employers (PPE users), governmental regulators, and the manufacturers, importers, distributors, and other suppliers of the PPE. Other stakeholders include standards development organizations (SDOs) and CA bodies (see Appendix A for additional information on CA bodies).

For the CA program owner, involving experts and stakeholders broadens the points of view and policy options that can be considered in designing and implementing the program. 
Input can also be obtained through a formal process or informally at conferences, workshops, and public calls for feedback. Overall, gaining the support of stakeholders will improve the quality of the program.

\subsubsection{Understanding CA Program Owner Responsibilities}

CA programs require an owner to design, manage, and monitor the program. The program owner can be any type of organization - public or private. Common types of organizations are government or regulatory bodies, non-governmental organizations, trade or manufacturing associations, product certification bodies or groups of certification bodies, suppliers, and consumer organizations [ISO/IEC 17067:2013]. The primary responsibilities of (certification) program owners are defined in ISO/IEC 17067:2013. The program owner should be a legal entity that, for example, has full responsibility for the objectives, content, and integrity of the program; sets up the structure for managing and operating the program; evaluates and manages risks/liabilities arising from the program; and has the financial stability and resources required for it to fulfill its role in the operation of the program.

Public sector programs require empowering legislation that grants the program owner the necessary powers to perform its functions. Section 2.1 discusses guidance to U.S. federal agencies and considerations in leveraging private sector activities. Regardless of program ownership, suppliers remain responsible for the conformity of the products they place on the market with relevant product requirements.

A program should be developed by persons competent in both technical and CA requirements, and should cover these elements:

- scope (type of product, circumstance of use);

- product requirements;

- CA activities, methods, and procedures;

- requirements for CA bodies (e.g., impartiality, independence, competence, accreditation, peer assessment);

- information supplied by supplier to support CA (e.g., technical file, designs);

- statement of conformity (e.g., supplier's declaration of conformity (SDoC), certification);

- mark of conformity (e.g., a label);

- list of approved products;

- required documentation for approved products;

- surveillance (when appropriate) and enforcement procedures; and

- corrective actions.

These elements are defined in ISO/IEC 17067:2013. Information on all requirements and procedures for obtaining CA should be publicly available [ACUS: 2012; ANSI: 2014b]. 


\subsubsection{Analyzing the Risk of I njury and I lness Associated with Non- conformity}

Analysis methods to determine the risk of non-conformity in a market vary depending on the product type, its use, and available data. Figure $\mathbf{3}$ shows a nine step risk analysis process that can be used to align the CA requirements with the associated risk. [NIOSH Docket 237-A]

This risk analysis process is a powerful tool in collecting information in a systematic, logical way. As such, the process outlined in Figure $\mathbf{3}$ can help

- identify significant gaps between CA activities and risk that the PPE would fail to meet performance standards,

- identify when the risk of non-conformance is eclipsed by the risk of an inadequate performance standard,

- provide a straightforward process that can facilitate thoughtful group discussion and decision making,

- justify decisions to make changes in CA activities,

- provide a basis of consistency in analysis between various PPE types.

Furthermore, this consistent analysis can aid prioritization of research activities and help align performance standards with appropriate conformity assessment activities. Limitations exist in fully benefiting from this process. These include the need to generate a great deal of data and the qualitative and subjective nature of the process. Moreover, risk assessment is not the only basis for defining an optimal CA program nor should it be the sole basis for justifying a change in the activities of an existing program.

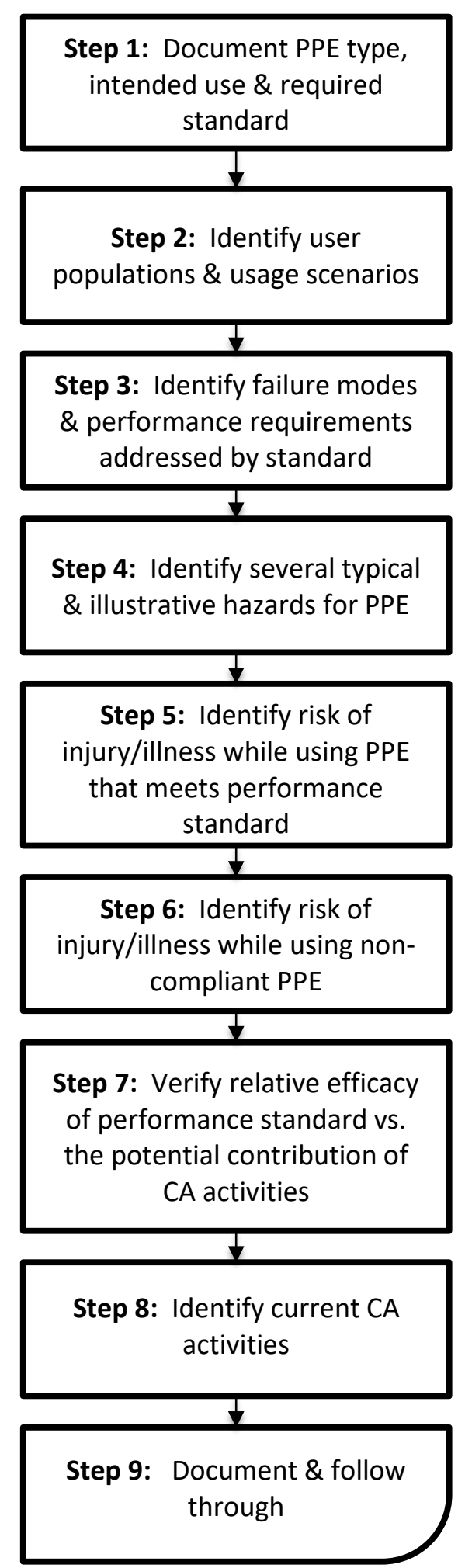

Figure 3. Analyzing risk for conformity assessment 


\subsubsection{I ndependence and Rigor}

CA activities range along a continuum of independence and rigor. Generally, as the seriousness of the hazard rises, CA activities should become more extensive [(i.e., rigorous)] [ISO, 2013a]. The greater the perceived risk, the more program owner oversight and conformity independence are needed in a CA program [Gillerman, 2004]. When the risks associated with a non-conforming PPE are low, first-party testing or inspection with a supplier's declaration can generally be considered adequate. When the risk is higher, testing by a third-party laboratory (with accreditation as a consideration) may be appropriate. For PPE designed to protect against the most serious hazards, certification by an accredited third party may be needed along with an accredited quality management system and a rigorous program of market surveillance.

Figure 4 illustrates examples of a continuum of independence and rigor with four hypothetical CA programs. With each increase in risk level, the independence and rigor of CA should increase, which in turn increases the resources needed to carry out the required CA activities. ISO/IEC 17067:2013[E] provides seven example CA systems that can be combined as needed to create a similarly wide spectrum of programs when the decision has been made to require third-party certification ${ }^{3}$

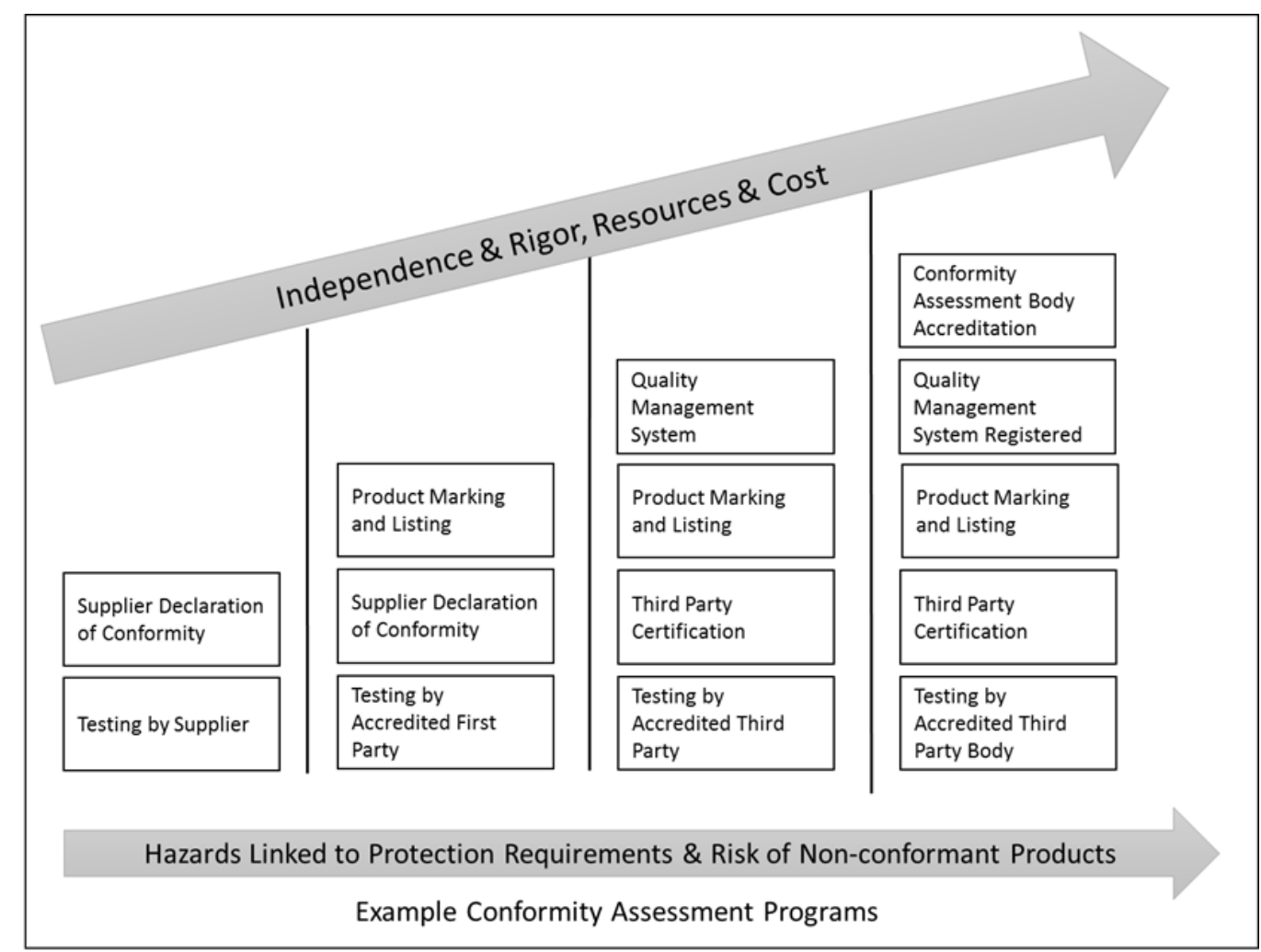

Source: Adapted from Carnahan (2013)

\section{Figure 4. Relating Risk to Rigor \& I ndependence}

Hazard and risk assessment using available data is the recommended approach for determining effective CA activities in managing worker exposures and defining the CA program. In the absence

\footnotetext{
${ }^{3}$ see Appendix C for complete information
} 
of data, as is the case with many PPE types, experts and other stakeholders must collaborate to determine the set of effective CA program requirements.

\subsubsection{Beyond Risk}

CA programs should be designed with a clear understanding of the assumptions that underlie the need for the program in addition to risk-based considerations. CA requirements should provide sufficient benefit in the form of needed assurance of "competence, consistency, and impartiality" to justify the cost and effort [ISO, 2012b]. A CA program owner should, therefore, balance the level of desired robustness of the program with cost and other factors. CA programs should be efficient, effective, and sustainable. A program that is too rigorous may prove too burdensome for suppliers; a program that is not rigorous enough may not provide the needed level of confidence in the PPE products.

In addition to the risks associated with non-conformity, design decisions for CA programs should consider the following factors:

- practical means of evaluating the characteristics of interest,

- scale and type of production,

- effectiveness of marketplace mechanisms to remove non-conforming products from the market,

- effectiveness of existing CA activities for a particular product or industry in preventing non-conforming products from reaching the market,

- effectiveness of penalties for placing non-conforming regulated products in the market, and

- effectiveness of systems to recall non-conforming regulated products from the market [Gillerman, 2004].

To facilitate trade and commerce, and not create a barrier to trade, the CA requirements should also be consistent with international CA standards for the desired activity ${ }^{4}$.

In some contexts, more than one program design could balance these various objectives for a given product category because some program elements help mitigate the potential loss of confidence due to less rigor and independence in other elements. For example, a robust market surveillance program backed up by effective enforcement mechanisms, corrective actions, and penalties for non-conformance can help achieve the needed balance for some programs that rely on a supplier's declaration of conformity.

\subsubsection{Connecting Levels of Risk and Appropriate CA Activities}

Consensus standards are available and others are being developed to provide guidance on connecting level of risk and risk management with appropriate CA activities for consideration by program owners. For example, ANSI/ISEA 125-2014 lists the following general assumptions in determining an appropriate PPE and CA category:

- Risks and hazards are contemplated based on reasonably expected outcomes, not imaginable best- or worst-case scenarios. Data should be used if available.

- The seriousness of an injury is evaluated on an objective basis and includes consideration of where the injury fits in the entire spectrum of workplace injuries. Highly

\footnotetext{
${ }^{4}$ See Table 1 for more information
} 
individualized and subjective outlooks regarding potential injury or illness should be avoided in establishing a PPE category.

- The user is wearing and using the PPE properly. Scenarios related to user misuse such as wearing spectacles down on the nose or tying high visibility apparel around the waist, should not be considered.

- The PPE was properly selected for the hazard and is appropriate for the reasonably expected outcomes and events within the environment.

- The PPE is maintained and inspected according to the manufacturer's instructions.

- The PPE-related "cause" of an injury is limited solely to incidents in which

0 the PPE does not perform as specified because of a non-conformance in the PPE that is not detectable to the user, or

0 the magnitude of the hazard or event does not exceed the performance ability of the PPE per the performance standard.

American National Standard for Conformity Assessment of Safety and Personal Protective Equipment [ANSI/ISEA 125-2014] defines three categories for PPE relative to risk.

"Level 1 can be used effectively where injury to the user is likely to be superficial and require only standard first aid or routine medical attention on a one-time basis". [ANSI/ISEA 125-2014]

“Level 2 PPE is intended to protect against dangers that may cause grave and irreversible injury or illness and for which the user is unlikely to be able to spot a defective condition in time to avoid injury or illness. Use of Level 2 PPE requires professional judgment and assistance in selection, use, and training. This level may include PPE to protect against mechanical and acoustic hazards." [ANSI/ISEA 125-2014]

“Level 3 PPE is intended to protect against mortal danger or against dangers that may cause grave and irreversible injury or illness and for which the user is unlikely to be able to spot a defective condition in time to avoid such mortal or grave injury or illness." [ANSI/ISEA 125-2014]

Table 1, extracted from ANSI/ISEA 125-2014, illustrates how specific CA activities could be combined to create CA programs at differing levels of robustness in activities and independence. Level 1 involves the least rigor and independence (relative to the other levels) and results in an SDoC. It could be considered most appropriate for CA of products designed to protect the user against gradual or unexceptional hazards.

Level 3 is the most rigorous and independent of these examples. Like Level 2, it requires testing by an accredited testing laboratory (level 2 does not have a third-party requirement). Level 3 requires certification by an accredited certification body. Further, the accreditation body must be a signatory, in good standing, to an appropriate international mutual recognition arrangement operating under relevant scope of CA activities (e.g., testing, certification, etc.).

Each level requires a quality management system that includes the manufacturing processes in its scope, with Levels 2 and 3 requiring registration of these systems. 
Table-1 Conformity Assessment Activities Based on Risk Category

\begin{tabular}{|c|c|c|c|}
\hline CA Activity & Level 1 & Level 2 & Level 3 \\
\hline $\begin{array}{l}\text { Quality management } \\
\text { system }\end{array}$ & $\begin{array}{l}\text { Scope includes } \\
\text { manufacturer of } \\
\text { specified product. } \\
\text { Must include initial } \\
\text { and ongoing } \\
\text { assurance of } \\
\text { conformity }\end{array}$ & $\begin{array}{l}\text { Supplier of OEM must } \\
\text { be registered to ISO } \\
9001 . \text { Scope includes } \\
\text { manufacturer of } \\
\text { specified product. } \\
\text { Must provide initial } \\
\text { and ongoing } \\
\text { assurance of } \\
\text { conformity }\end{array}$ & $\begin{array}{l}\text { As determined by the } \\
\text { third-party certification } \\
\text { organization. Must } \\
\text { provide initial and } \\
\text { ongoing assurance of } \\
\text { conformity }\end{array}$ \\
\hline Test facility criteria & $\begin{array}{l}\text { As determined by the } \\
\text { supplier }\end{array}$ & $\begin{array}{l}\text { In-house or } \\
\text { independent third } \\
\text { party, as determined } \\
\text { by the supplier; } \\
\text { ISO/IEC } 17025 \\
\text { accreditation required }\end{array}$ & $\begin{array}{l}\text { As directed by the } \\
\text { certification } \\
\text { organization: ISO/IEC } \\
17025 \text { accreditation } \\
\text { required }\end{array}$ \\
\hline $\begin{array}{l}\text { Retesting determined } \\
\text { by whom? }\end{array}$ & Supplier & Supplier & $\begin{array}{l}\text { Third-party certification } \\
\text { organization }\end{array}$ \\
\hline Test interval & $\begin{array}{l}\text { At least every five } \\
\text { (5) years }\end{array}$ & $\begin{array}{l}\text { At least every five (5) } \\
\text { years }\end{array}$ & $\begin{array}{l}\text { As determined by the } \\
\text { certification } \\
\text { organization, at least } \\
\text { every five (5) years }\end{array}$ \\
\hline $\begin{array}{l}\text { Corrective and } \\
\text { preventative action }\end{array}$ & $\begin{array}{l}\text { Supplier to establish } \\
\text { and maintain written } \\
\text { program }\end{array}$ & $\begin{array}{l}\text { Supplier to establish } \\
\text { and maintain written } \\
\text { program }\end{array}$ & $\begin{array}{l}\text { Supplier to establish and } \\
\text { maintain written } \\
\text { program }\end{array}$ \\
\hline $\begin{array}{l}\text { Product recalls/safety } \\
\text { alerts }\end{array}$ & $\begin{array}{l}\text { Supplier to establish } \\
\text { and maintain written } \\
\text { program }\end{array}$ & $\begin{array}{l}\text { Supplier to establish } \\
\text { and maintain written } \\
\text { program }\end{array}$ & $\begin{array}{l}\text { Supplier to establish and } \\
\text { maintain written } \\
\text { program }\end{array}$ \\
\hline Record keeping & $\begin{array}{l}\text { Record retention } \\
\text { policy }\end{array}$ & $\begin{array}{l}\text { Record retention } \\
\text { policy }\end{array}$ & Record retention policy \\
\hline $\begin{array}{l}\text { Declaration of } \\
\text { conformity }\end{array}$ & Supplier & Supplier & $\begin{array}{l}\text { Third-party certification } \\
\text { organization issues } \\
\text { certificate and supplier } \\
\text { applies certification } \\
\text { mark to product }\end{array}$ \\
\hline
\end{tabular}

\subsubsection{Considerations for a First-Party Attestation}

When a supplier declaration of conformity (SDoC) is used for attestation, suppliers should consider using the requirements of ISO/IEC 17050:2004. Per the ISO standard, SDoCs should:

- be based on results of an appropriate type of CA activity (e.g., testing, measurement, auditing, inspection, or examination) carried out by one or more first, second, or third parties;

- be based on relevant international standards, guides, and other normative documents, where applicable; and

- be signed by someone other than the person reviewing the CA results.

Suppliers should consider the following elements in the SDoC: 
- a unique identification number;

- the name and contact information of the supplier;

- a description of the product and production process;

- the statement of conformity;

- the technical performance standards, the date, and place at which the SDoC was issued as well as other pertinent information.

If other parties were involved with the CA (e.g., a third-party testing laboratory), the name and contact information for those bodies should also be included on the SDoC along with relevant CA reports. The supplier should also have procedures in place to ensure the continued conformity of the product and to reevaluate the validity of the SDoC when significant changes are made to the product's design, when the supplier's ownership or management changes, and when information is received indicating the product is no longer conforming to the requirements (e.g., recall notification).

\subsubsection{Considerations for Third-Party Use and Attestation}

When third-party involvement is required for CA activities, CA program owners should employ third-party bodies that are independent of the person or organization that provides the PPE and impartial so that the results of their work can be objective. Program owners should consider the use of accredited third parties when an independent assessment of management system and technical competence requirements exists. Accreditation should be based on the ISO Committee on Conformity Assessment (CASCO) standards and guidelines. Third parties can be government laboratories or private sector organizations.

Program owners using certification bodies should consider the requirements specified in ISO/IEC 17065: 2012 for certification bodies. These include:

- impartiality;

- the use of specific product standards;

- a quality management system;

- specified conditions and procedures for granting, maintaining, and extending certification, and for suspending or withdrawing certification;

- procedures for assessing the effects of significant changes in product design or specification, or in the ownership or administration of the product's supplier;

- periodic internal audits and management reviews;

- documentation and recordkeeping;

- confidentiality measures;

- competent personnel;

- appeals procedures; and,

- a documented surveillance procedure.

When accreditation is required, accreditation bodies should demonstrate that they are independent, unbiased, and competent by fulfilling the requirements specified by ISO/IEC 17011:2004. Further, program owners should consider a requirement that accreditation bodies be signatories, in good standing, to an appropriate international mutual recognition agreement operating under relevant scope of CA activities (e.g., testing, certification, etc.), and be subjected to peer reviews. 
Many U.S. CA program owners have requirements for third-party certification bodies such as NFPA, NIJ, USCG and the Federal Aviation Administration. The box below provides a specific example of ISO CASCO standards used in augmenting standard requirements.

\section{EXAMPLE: PROGRAMS CAN USE ISO CASCO STANDARDS FOR BASE REQUI REMENTS AND AUGMENT THEM FOR THE PPE INDUSTRY}

The National Fire Protection Association (NFPA) does not certify or otherwise attest to the conformance of products to its standards. Rather products are certified as conformant by third-party certification bodies based in part on test results performed by first- or third-party testing laboratories and successful implementation of a quality management system for product production. How can the NFPA and purchasers have confidence in these certifications? The NFPA relies on the ISO CASCO standards as requirements for certifiers, testing laboratories, and quality management registrars. Further the NFPA requires these organizations be accredited as meeting the requirements of these standards; and that the accreditors are also conformant to ISO CASCO standards. The NFPA augments the ISO CASCO requirements with a detailed set of PPE-related requirements for activities such as test method use, surveillance, and retesting; product labeling; complaints; and non-conformity identification.

\subsubsection{Labels, Product Lists, and Other Documentation of Conformity}

Products that meet all the applicable requirements should be accompanied by a statement of conformity such as an SDoC or a third-party certificate of conformity.

Certification program owners should establish and maintain lists of certified products to help consumers identify PPE that is conformant to specified standards. In those standards where hazards are linked to measurable protection requirements, users can have more confidence that conformant products provide adequate protection. The listing activity should follow CASCO standards. ISO/IEC 17065:2012 requires certification listings to include information about the specific product or type of product certified, the qualification standard that the product is judged to meet, and the date of certification (and if applicable, its expiration).

Suppliers should also consider, where applicable, identifying the standards and requirements that the product fulfills, based on conformity, in the user instructions, to enable users to easily know the level of protection provided.

\subsubsection{Design Market Surveillance Strategies}

PPE products are designed to protect the user against hazards; thus, market surveillance programs should consider an analysis of the seriousness of the hazard. A consideration should be made to follow CASCO's best practice guidelines [ISO, 2012a] for market surveillance.

Market surveillance includes both pre-market and post-market surveillance. Pre-market surveillance involves gathering evidence of conformity at the point of production or in the supply chain. Management system records as part of the manufacturing process can contribute to this 
evidence. Post-market surveillance involves gathering evidence of conformity in the marketplace and/or at the place of use.

A risk assessment process is one tool that can be used to help define market surveillance requirements. Input into the risk process can be drawn from sources (as appropriate) such as accident reports and statistics; reports from workers or worker organizations; reports from manufacturers, suppliers, importers, or retailers; consumer alert systems; reports to and from federal agencies; the media; and data from previous market surveillance activities.

These reports from PPE users and others associated with a product non-conformance should be carefully considered and properly verified. Not all complaints will be about safety problems or health and safety-related non-conformities. A method to assess various reports should be established to determine relevant complaints and reports.

Figure 5 summarizes the steps of post-market surveillance. The program owner should consider the following:

- Which businesses are examined and at what rate or timeframe?

- Which products should be sampled?

- How many samples should be selected and to which tests should the samples be subjected?

- Should the products be tested physically or should the investigation be limited to documentary checks? Should testing be first, second, or third party?

- Should the products be sampled at the point of distribution or by the manufacturers, suppliers, and importers?

- Which documents should be requested from the supplier and checked? [Adapted from PROSAFE: 2009]

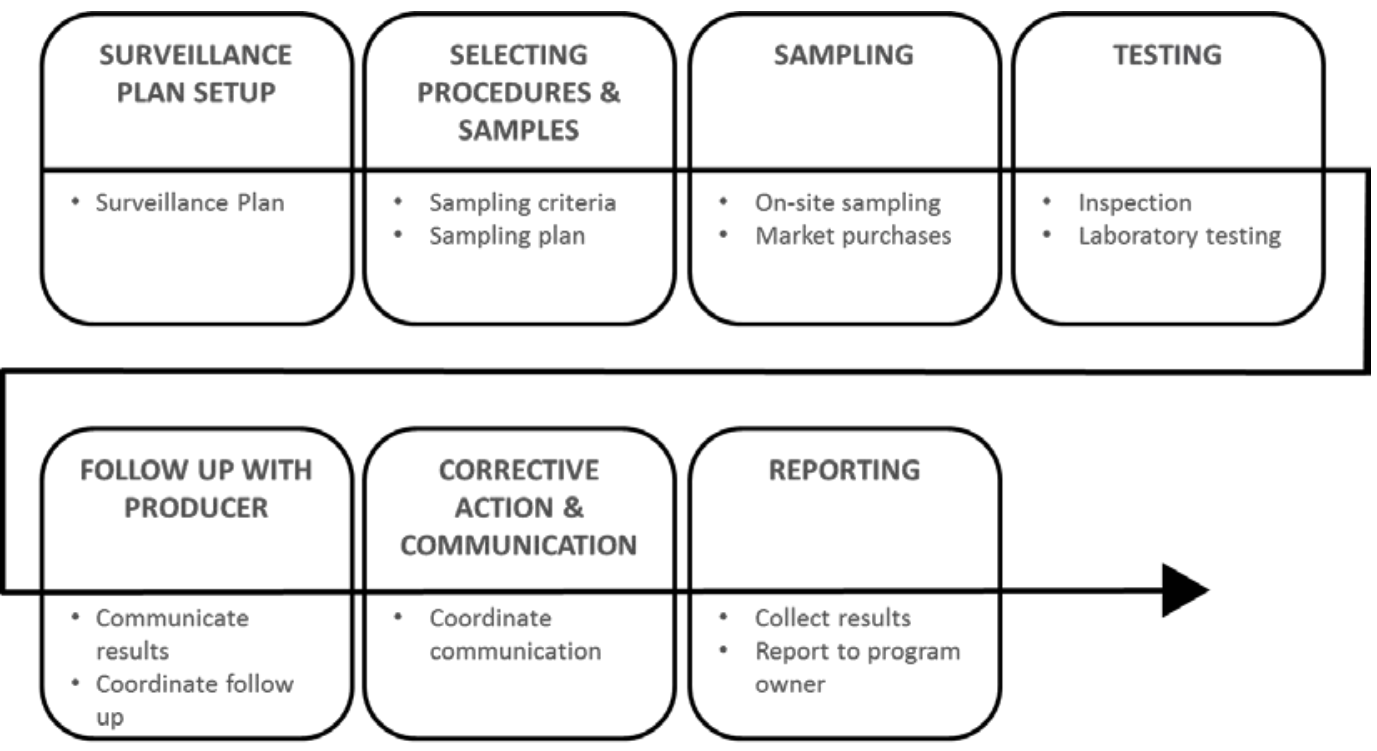

\section{Figure 5. Post Market Surveillance Action [Adapted from PROSAFE:2009, Fig 26]}

The figure above provides an example of how surveillance is used as a feedback mechanism. 


\subsection{Step 5: Perform CA Activities}

\section{EXAMPLE: SURVEI LLANCE REQUI REMENTS CAN OFFER MANUFACTURERS FLEXI BI LI TY FOR COMPLI ANCE}

The National Institute of Justice Compliance Testing Program (NIJ CTP) administers a program to test commercially available body armor for compliance with standards to determine whether the vests will perform as expected. Satisfactory participation in the Follow-up Inspection and Testing (FIT) Program is required for continued attestation by the program. The FIT program requires the destructive testing and inspection of model samples as well as an inspection site visit to each manufacturing location - typically at least once every 10 months. If the product model is manufactured under an NIJ CTPapproved body armor quality management system (BA-QMS), the frequency of inspection for that model/location may be reduced to once every 20 months.

A CA program is successful if it provides confidence in claims of conformance; serves as a communication tool between buyers and sellers; and adapts to changes in standards, risk, technology, and the market. A CA program implements processes and activities in the most effective and efficient manner while seeking to impact the areas above.

\subsubsection{Conformity Assessment I mprovement Activities}

CA programs are periodically reviewed from both effectiveness and cost/benefit perspectives to help maintain the desired level of confidence at the most efficient cost. Accreditation requirements are used as a tool to continuously improve the activities of accredited CA bodies (e.g., testing laboratories, inspection bodies, and certification bodies). CA program metrics can include the number of organizations with products tested and attestations made, the status of the product list maintained by the program (additions, suspensions, and removals), the number of product complaints, etc. Other CA program indicators include: use and market recognition by purchasers; ability to react to updated standards and new versions of standards; and ability to react to new product technology and test methods. Such indicators allow CA programs to identify and make necessary adjustments to improve the program's efficiency and effectiveness.

\subsubsection{Surveillance Activities}

Surveillance procedures are undertaken to ensure continued product conformity and integrity of the CA mark and program. PPE products are designed to protect the user against hazards; thus, program owners should select surveillance procedures based on factors such as the seriousness of the hazard, risk of non-conformance, and level of confidence desired in the program. Reactive surveillance actions may be sufficient for low-risk scenarios. For higher risk scenarios, more proactive surveillance activities can include periodic testing of sample products or the periodic assessment of management system requirements for the manufacturing processes. Surveillance procedures can also involve responding to validated reports of non-conforming products [ISO, 2012a]. 


\section{Conclusions}

MSHA, OSHA, and other regulatory agencies require that employers protect their employees from workplace hazards that can cause injury. Mitigating the risks to worker health and safety at the source is the best way to protect employees. However, when engineering controls and administrative controls are not feasible or do not provide sufficient protection, PPE is needed. Although OSHA publishes guidance for effective worker protection using PPE, there is currently no single regulatory body, official guidance, or mandating authority for conformity assessment of all PPE in the United States. In the absence of national policy, this Framework provides a risk-based, evidence-driven approach on how to tailor conformity assessment activities.

The Framework is intended to serve as foundational principles for various types of conformity assessment programs for occupational PPE. They are not requirements for how these programs must, or will, function. Conformity assessment activities should be tailored to the needs of product users, suppliers, and regulatory authorities. They should result in products that protect workers who rely on PPE; facilitate trade, fair competition, and market access; be cost-effective; and provide assurance of conformance. 


\section{References}

ACUS [2012]. Administrative Conference Recommendation. Agency Use of Third-Party Programs to Assess Regulatory Compliance. Washington, DC: Administrative Conference of the U.S. Adopted December 6, 2012. http://www.acus.gov/recommendation/agency-use-third-party-programsassess-regulatory-compliance

ANSI [2014a]. U.S. Conformity Assessment System: Key Organizations. Washington, DC: American National Standards Institute http://www.standardsportal.org/usa_en/conformity_assessment/key_organizations.aspx

ANSI [2014b]. National Conformity Assessment Principles for the U.S. Washington, DC: American National Standards Institute.

http://www.standardsportal.org/usa_en/conformity_assessment/conformity_assessment.aspx

ANSI [2010]. United States Standards Strategy. Washington, DC: American National Standards Institute. http://www.ansi.org/standards_activities/nss/usss.aspx?menuid=3

ANSI/ISEA [2014]. ANSI/ISEA Z89.1-2014 Industrial Head Protection. Washington, DC: American National Standards Institute. https://safetyequipment.org/standard/ansiisea-z89-1-2014/

ANSI/ISEA [2014]. 125-2014 Conformity Assessment of Safety and Personal Protective Equipment. Washington, DC: American National Standards Institute. https://safetyequipment.org/isea-standards/conformity-assessment/

ASTM F1818-13 Standard Specification for Foot Protection for Chain Saw Users. West Conshohocken, PA: American Society for Testing and Materials.

http://www.astm.org/Standards/F1818.htm

ASTM F2669-12 Standard Performance Specification for Protective Clothing Worn by Operators Applying Pesticides. West Conshohocken, PA: American Society for Testing and Materials. http://www.astm.org/Standards/F2669.htm

Breitenberg MA [1997]. The ABC'S of the U.S. Conformity Assessment System. NISTIR 6014. Gaithersburg, MD: National Institute of Standards and Technology.

http://gsi.nist.gov/global/docs/pubs/NISTIR_6014.pdf

Carnahan [2013]. "US Conformity Assessment Capabilities and Infrastructure". Presented at NIOSH Personal Protective Equipment Conformity Assessment Public Meeting, September 17, 2013.

Bloodborne Pathogens. 29 CFR 1910.1030. [2010].

http://www.gpo.gov/fdsys/pkg/CFR-2010-title29-vol6/pdf/CFR-2010-title29-vol6-sec19101030.pdf

European Cooperation for Accreditation (EA) [2014].

http://www.european-accreditation.org/home

EPA (2014). Occupational Pesticide Handler Exposure Data. United States Environmental Protection Agency. http://www.epa.gov/opp00001/science/handler-exposure-data.html 
Gillerman, G [2004]. Making the Confidence Connection: Conformity Assessment System Design. Standardization News. American Society for Testing and Materials.

http://www.astm.org/SNEWS/DECEMBER_2004/gillerman_dec04.html

IAAC (2014). InterAmerican Accreditation Cooperation. http://www.iaac.org.mx/English/Intro.php

IOM [2008]. The Personal Protective Technology Program at NIOSH. Institute of Medicine and National Research Council. Washington, DC: The National Academies Press.

http://www.nap.edu/catalog.php?record_id=12203

IOM [2011]. Certifying Personal Protective Technologies: Improving Worker Safety. Institute of Medicine. Washington, DC: National Academies Press.

http://www.nap.edu/catalog/12962/certifying-personal-protective-technologies-improving-workersafety

ISO/IEC 17000:2004 Conformity assessment - Vocabulary and general principles.

https://www.iso.org/standard/29316.html

ISO/IEC 17067:2013[E] Conformity Assessment - Fundamentals of product certification and guidelines for product certification schemes. Geneva, Switzerland: International Organization for Standardization.

http://www.iso.org/iso/iso_catalogue/catalogue_tc/catalogue_detail.htm?csnumber $=55087$

ISO [2012a]. Principles and Practices in Product Regulation and Market Surveillance. Geneva, Switzerland: International Organization for Standardization.

http://www.iso.org/iso/home/store/publications_and_e-

products/publication item.htm?pid=PUB100321

ISO [2012b]. Contextual changes in product certification since ISO/IEC Guide 65 publication. Geneva, Switzerland: International Organization for Standardization.

http://www.iso.org/iso/2012_casco_explanation_revision_from_guide_65.pdf

ISO [2013a]. Resources for Conformity Assessment. The CASCO Toolbox. Geneva, Switzerland: International Organization for Standardization. http://www.iso.org/iso/home/about/conformityassessment/conformity-assessment_resources.htm

ISO [2013b] Standards Catalogue. ISO/CASCO - Committee on Conformity Assessment. Geneva, Switzerland: International Organization for Standardization.

http://www.iso.org/iso/home/store/catalogue_tc/catalogue_tc_browse.htm?commid=54998\&publis $\underline{\text { hed }=\text { on\&includesc }=\text { true }}$

ISO/IEC 17065:2012. Conformity assessment-Requirements for bodies certifying products, processes and services. Geneva, Switzerland: International Organization for Standardization. http: // www.iso.org/iso/catalogue_detail?csnumber $=46568$

ISO-UNIDO [2010]. Building Trust, the Conformity Assessment Toolbox. Geneva, Switzerland: International Organization for Standardization. http://www.iso.org/iso/casco_building-trust.pdf

Main, B [2004]. Risk Assessment: Basics and Benchmarks. Ann Arbor, MI. ISBN: 0-9741248-0-8.

NIOSH Docket 237-A Docket 237-A - www.cdc.gov/niosh/docket/archive/docket237A.html 
NIJ [2013] National Institute of J ustice Conformance Testing Program Ballistic Agreement. Rev. 14 June 2013. OMB Number 1121-0321.

http://www.reginfo.gov/public/do/DownloadDocument?objectlD=36104001

NIST [2012]. NIST Guidance on Federal Conformity Assessment Activities (15 C.F.R. Part 287). Presented at the Public Workshop.

http://www.nist.gov/director/sco/ca-workshop-2012.cfm

NTTAA, National Technology Transfer and Advancement Act. [1996]. Public Law 104-113.

http://www.gpo.gov/fdsys/pkg/PLAW-104publ113/pdf/PLAW-104publ113.pdf

Office of the United States Trade Representative, https://ustr.gov/trade-agreements/wto-multilateralaffairs/wto-issues/technical-barriers-trade, accessed 10/12/2017

OMB [1998]. Federal Participation in the Development and Use of Voluntary Consensus Standards and in Conformity Assessment Activities. Circular A-119. Washington, DC: Office of Management and Budget. http://www. whitehouse.gov/omb/circulars_a119

OMB [2003]. Regulatory Analysis. Circular A-4. Washington, DC: Office of Management and Budget. http://www.whitehouse.gov/omb/circulars_a004_a-4/

OSHA [2002]. Job Hazard Analysis, OSHA 3071. Washington, DC: U.S. Department of Labor, Occupational Safety and Health Administration. https://www.osha.gov/Publications/osha3071.pdf

OSHA [2003]. Personal Protective Equipment, OSHA 3151-12R. Washington, DC: U.S. Department of Labor, Occupational Safety and Health Administration.

https://www.osha.gov/Publications/osha3151.pdf

PROSAFE [2009]. Best Practice Techniques in Market Surveillance. Brussels, Belgium: PROSAFE. http: //www.prosafe.org/index.php?option=com_content\&view=article\&id=15\&l temid=254

Rodriguez, JA [2013]. "PPE User's (Industry) Perspective on Why PPE Conformity Assessment Standards Form a Part of an Overall Protective Strategy". Raytheon Technical Services Company LLC, presented at American Industrial Hygiene Association Conference and Exposition 2013, Montreal, Canada.

SafeWork SA [2014]. How to Manage Work Health and Safety Risks.

http://www.safework.sa.gov.au/show_page.jsp?id=113695

Safe Work Australia [2011]. How to Manage Work Health and Safety Risks Code of Practice. http://www.safeworkaustralia.gov.au/sites/swa/about/publications/pages/manage-whs-risks-cop

The White House [2011]. Presidential Documents: Executive Order 13563 --Improving Regulation and Regulatory Review. Executive Order. Federal Register 76(14)3821 (2011).

http://www.reginfo.gov/public/isp/Utilities/EO_13563.pdf

WTO TBT. Agreement on Technical Barriers to Trade. World Trade Organization.

https://www.wto.org/english/docs_e/legal_e/17-tbt.pdf

Unger P and Dougherty R [2012]. “The International Laboratory Accreditation Cooperation (ILAC) \& the International Accreditation Forum (IAF)." Presented at the NIST Conformity 
Assessment Workshop on April 11, 2012.

https://www. nist.gov/sites/default/files/documents/director/sco/5 2-and-3-Joint IAF_LAC.pdf

\section{Appendix A CONFORMITY ASSESSMENT ACTI VITIES}

\section{Conformity Assessment Activities}

Selecting information about the product involve (1) identifying the product requirements and referenced standard(s) or other document(s) to which conformity is to be assessed, and (2) selecting examples of the product to be assessed using statistical sampling techniques, if applicable.

Gathering evidence of conformity (also referred to as "Determination") includes one or more of the following: testing to determine specified characteristics of the product; inspection of physical features of the product (e.g., visual examination of a physical item, measurement or testing of physical items, examination of design drawings or other specification documents); and auditing of supplier's quality system and records relating to the product.

Reviewing the evidence and making a decision about conformity involves assessing the suitability, adequacy, and effectiveness of the selection and determination activities, and the result of those activities, and then deciding whether the product conforms based on the evidence gathered.

Attesting to conformity includes the Supplier's Declaration of Conformity (SDoC), third-party certificate of conformity, and marks of conformity.

Conducting market surveillance includes both proactive and reactive actions. These elements include both pre-market surveillance (gathering evidence of conformity at the point of production or in the supply chain to the marketplace) and post-market surveillance (gathering evidence of conformity in the marketplace and/or at the place of use).

Taking enforcement and corrective actions include official warnings, customer alerts, sales bans, sales suspensions, product withdrawals and recalls, and fines.

Using mechanisms to ensure that all service providers are competent, includes accreditation, auditing, and peer evaluation.

Program owners determine how each of these activities is to be conducted. The interrelationship of these activities is illustrated in Figure A-1. 


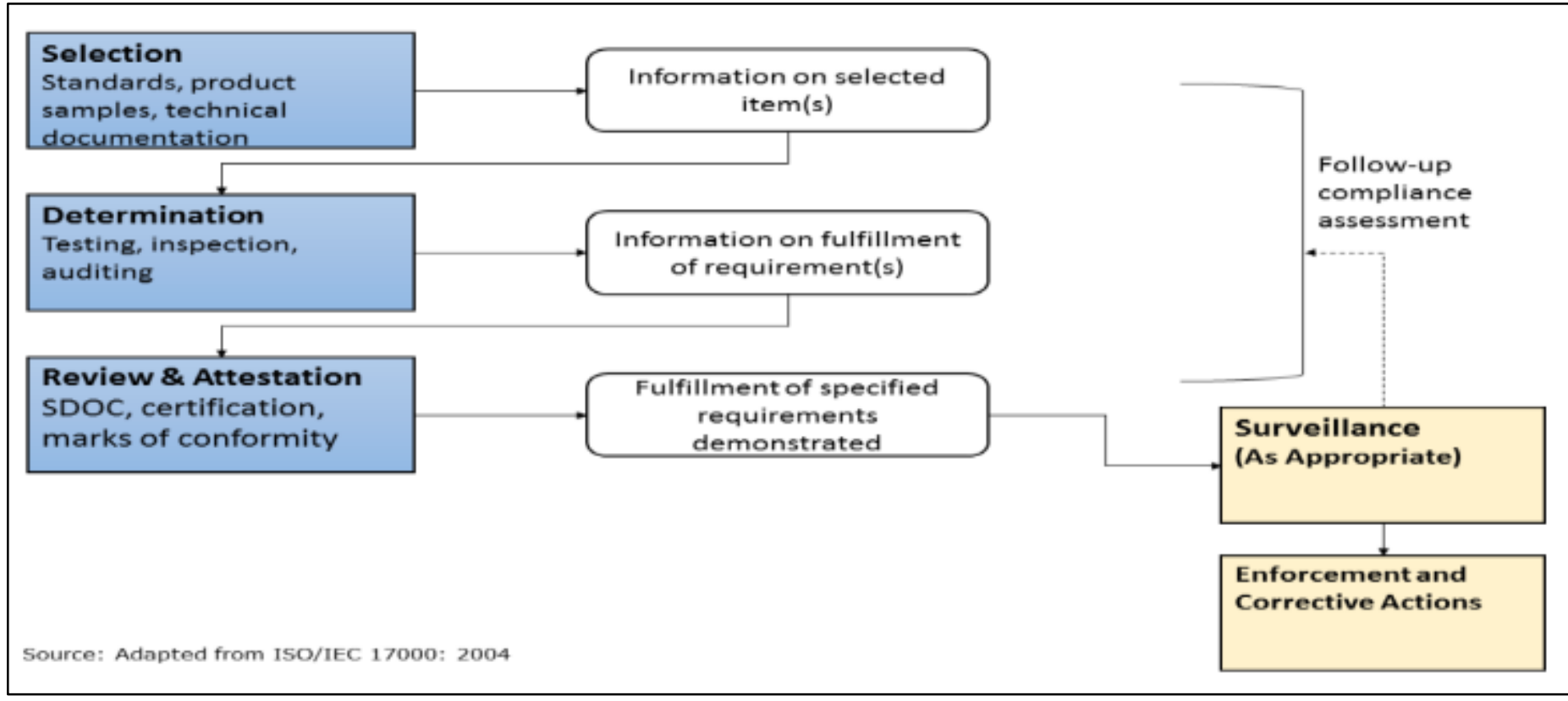

Figure A-1. Functional Approach to Conformity Assessment

Organizations developing a CA program should fully understand the benefits and costs associated with the implementation and use of these activities. Below are commonly used CA activities5:

- Testing is defined in ISO/IEC 17000 as the "determination of one or more characteristics of an object of conformity assessment, according to a procedure," also known as a test method. The objects of testing are generally selected using some form of sampling procedure or process. Testing can be performed by laboratories differing widely in size, legal status, purpose, range of testing services offered, and technical competence. Testing can be performed by first, second, or third parties. ISO/IEC 17025:2005 "specifies the general requirements for the competence to carry out tests and/or calibrations, including sampling. It covers testing and calibration performed using standards methods, non-standards methods, and laboratory-developed methods."

- Inspection is defined in ISO/IEC 17000 as "examination of a product design, product, process, or installation and determination of its conformity with specific requirements, or on the basis of professional judgment, with requirements." Inspection can be performed by first, second, or third parties. Generally, inspection systems demonstrate conformity of only the actual products inspected or a lot from which the inspected samples are drawn. ISO/IEC 17020 specifies requirements for the competence of bodies performing inspection and for the impartiality and consistency of their inspection activities.

- A Supplier's Declaration of Conformity (SDoC), sometimes called a Manufacturer's Declaration of Conformity or even (incorrectly) self-certification, is a first-party assessment in which a supplier or manufacturer provides written assurance of conformity. ISO/IEC 17050 Parts 1 and 2 define requirements for suppliers and manufacturers to meet when they make formal claims that products, services, systems, processes, or materials conform to relevant standards, regulations, or other specifications.

\footnotetext{
${ }^{5}$ See Appendix B for references to the standards used in this section.
} 
- Certification is the process of providing assurance that a product conforms to a standard or specification or that a person is competent to perform a certain task. A third party (i.e., the certification body), independent of the manufacturer attests to the conformity of the product. ISO/IEC 17065 specifies requirements for organizations serving as certification bodies.

- A Management System establishes a framework of processes and procedures against which an organization can evaluate its performance in a particular area of interest (quality, environmental management, occupational safety and health, etc.). It involves the use of such techniques as written procedures and records, adequately trained staff and sufficient resources, internal audits, and management reviews. While the assessment of an organization's conformance to a particular management system standard can be carried out by a first or second party, management system registration (also known as certification) is a process in which an independent, third-party registrar evaluates and verifies that the organization has met the requirements of a specific management system standard. The registrar will then issue some type of written attestation of the conformance, such as a certificate of registration. ISO/IEC 17021 contains requirements for third-party bodies that operate a registration/certification program for the audit and certification of management systems.

- Accreditation is defined in ISO/IEC 17000 as a "third-party attestation related to a conformity assessment body conveying formal demonstration of its competence to carry out specific conformity assessment tasks." ISO/IEC 17011 specifies the requirements for organizations operating as an accreditation body accrediting CA bodies (e.g., testing laboratories, inspection bodies, certification bodies, and management system registrars). Accreditation bodies can be signatories, in good standing, to an appropriate international multilateral agreement operating under a relevant scope of CA activities (e.g. testing, certification, etc.) and be subjected to peer reviews.

- Mutual Recognition - The United States benefits from recognition of CA organizations through numerous international and regional arrangements. These arrangements reduce CA costs as well as build confidence among industry stakeholders that products produced abroad meet the U.S. standards for quality, safety, and health. The United States participates in different CA approaches regarding mutual recognition arrangements as well as international CA programs.

Table B-1 presents the mutual recognition arrangements relied on by U.S. conformity assessment programs. These mutual recognition arrangements help give U.S. conformity assessment program owners confidence in the conformity assessment bodies used outside the United States. These arrangements cover the conformity assessment activities of testing, certification, management systems and inspection. 
ISO/IEC's CA standards serve as the basis for CA requirements in many programs in the U.S. and elsewhere. The standards have been adopted and commonly used by federal agencies, foreign countries and regions, private regulators (e.g., in the food, telecommunications, and automotive industries), and accreditation schemes.

Table B-1 ISO Standards and Conformity Assessment

\begin{tabular}{|c|c|c|c|}
\hline Testing & Certification & Management Systems & I nspection \\
\hline $\begin{array}{c}\text { Mutual Recognition } \\
\text { Agreement } \\
\text { (ILAC, APLAC, EA, } \\
\text { IAAC)* }\end{array}$ & $\begin{array}{c}\text { Multilateral } \\
\text { Recognition } \\
\text { Agreement } \\
(I A F, \text { IAAC, PAC, EA }) *\end{array}$ & $\begin{array}{c}\text { Multilateral } \\
\text { Recognition } \\
\text { Agreement } \\
(I A F, \text { IAAC, PAC)* }\end{array}$ & $\begin{array}{c}\text { Mutual Recognition } \\
\text { Agreement } \\
\text { (ILAC, APLAC, EA, } \\
\text { IAAC)* }\end{array}$ \\
\hline $\begin{array}{l}\text { accreditation bodies } \\
\text { (ISO/IEC 17011) }\end{array}$ & $\begin{array}{l}\text { accreditation bodies } \\
\quad(\text { ISO/IEC 17011) }\end{array}$ & $\begin{array}{l}\text { accreditation bodies } \\
\text { (ISO/IEC 17011) }\end{array}$ & $\begin{array}{l}\text { accreditation bodies } \\
\text { (ISO/IEC 17011) }\end{array}$ \\
\hline $\begin{array}{l}\text { accredited testing and } \\
\text { calibration } \\
\text { laboratories } \\
\text { (ISO/IEC 17025) }\end{array}$ & $\begin{array}{c}\text { product certification } \\
\text { bodies } \\
\text { (ISO/IEC 17065) }\end{array}$ & $\begin{array}{c}\text { management system } \\
\text { certification bodies } \\
\text { (ISO/IEC 17021) }\end{array}$ & $\begin{array}{l}\text { inspection bodies } \\
\text { (ISO/IEC 17020) }\end{array}$ \\
\hline $\begin{array}{l}\text { samples } \\
\text { (Test methods and } \\
\text { sampling methods) }\end{array}$ & $\begin{array}{l}\text { products and services } \\
\text { (appropriate product or } \\
\text { service standards) }\end{array}$ & $\begin{array}{c}\text { companies or } \\
\text { organizations } \\
\text { (ISO } 9000, \text { ISO } 14000, \\
\text { or equivalent) }\end{array}$ & $\begin{array}{c}\text { products } \\
\text { (appropriate product } \\
\text { standards) }\end{array}$ \\
\hline
\end{tabular}

* APLAC - Asia Pacific Laboratory Accreditation Cooperation

* IAAC - Inter American Accreditation Cooperation

* IAF - International Accreditation Forum

* ILAC - International Laboratory Accreditation Cooperation

* EA - European Co-operation for Accreditation

* PAC - Pacific Accreditation Cooperation 
Table B-2 ISO/ IEC Conformity Assessment Standards

\begin{tabular}{|c|c|c|}
\hline Topic & Standard & Title \\
\hline Impartiality & $\begin{array}{l}\underline{\text { ISO/PAS }} \\
\underline{17001: 2005}\end{array}$ & $\begin{array}{l}\text { Conformity assessment }- \text { Impartiality }- \text { Principles and } \\
\text { requirements }\end{array}$ \\
\hline Code of good practice & $\begin{array}{l}\underline{\text { ISO/IEC }} \\
\underline{\text { Guide }} \\
\underline{60: 2004}\end{array}$ & Conformity assessment - Code of good practice \\
\hline Accreditation bodies & $\begin{array}{l}\underline{\text { ISO/IEC }} \\
\underline{17011: 2004}\end{array}$ & $\begin{array}{l}\text { Conformity assessment - General requirements for accreditation } \\
\text { bodies accrediting conformity assessment bodies }\end{array}$ \\
\hline Inspection bodies & $\begin{array}{l}\underline{\text { ISO/IEC }} \\
\underline{17020: 2012}\end{array}$ & $\begin{array}{l}\text { Conformity assessment - Requirements for the operation of } \\
\text { various types of bodies performing inspection }\end{array}$ \\
\hline $\begin{array}{l}\text { Audit and certification } \\
\text { bodies }\end{array}$ & $\begin{array}{l}\text { ISO/IEC } \\
17021: 2011\end{array}$ & $\begin{array}{l}\text { Conformity assessment - Requirements for bodies providing } \\
\text { audit and certification of management systems }\end{array}$ \\
\hline $\begin{array}{l}\text { Audit and certification } \\
\text { bodies }\end{array}$ & $\frac{1 \mathrm{SO} / \mathrm{IEC} \text { TS }}{\underline{17021-}}$ & $\begin{array}{l}\text { Conformity assessment - Requirements for bodies providing } \\
\text { audit and certification of management systems - Part 3: } \\
\text { Competence requirements for auditing and certification of quality } \\
\text { management systems }\end{array}$ \\
\hline $\begin{array}{l}\text { Testing and calibration } \\
\text { laboratories }\end{array}$ & $\frac{\text { ISO/IEC }}{\underline{17025: 2005}}$ & $\begin{array}{l}\text { General requirements for the competence of testing and } \\
\text { calibration laboratories }\end{array}$ \\
\hline Peer assessment & $\frac{\text { ISO/IEC }}{\underline{17040: 2005}}$ & $\begin{array}{l}\text { Conformity assessment - General requirements for peer } \\
\text { assessment of conformity assessment bodies and accreditation } \\
\text { bodies }\end{array}$ \\
\hline Proficiency testing & $\frac{\text { ISO/IEC }}{\underline{17043: 2010}}$ & $\begin{array}{l}\text { Conformity assessment - General requirements for proficiency } \\
\text { testing }\end{array}$ \\
\hline Certification bodies & $\begin{array}{l}\text { ISO/IEC } \\
17065: 2012\end{array}$ & $\begin{array}{l}\text { Conformity assessment - Requirements for bodies certifying } \\
\text { products, processes and services }\end{array}$ \\
\hline Certification bodies & $\frac{\text { ISO/IEC }}{17024: 2012}$ & $\begin{array}{l}\text { Conformity assessment - General requirements for bodies } \\
\text { operating certification of persons }\end{array}$ \\
\hline \multicolumn{3}{|c|}{ Conformity assessment systems } \\
\hline $\begin{array}{l}\text { Third-party body } \\
\text { certification }\end{array}$ & $\begin{array}{l}\underline{\mathrm{ISO} / \mathrm{IEC}} \\
\underline{\text { Guide 28: }} \\
\underline{2004}\end{array}$ & $\begin{array}{l}\text { Conformity assessment - Guidance on a third-party certification } \\
\text { system for products }\end{array}$ \\
\hline Product certification & $\underline{\underline{\text { ISO/IEC }}}$ & $\begin{array}{l}\text { Conformity assessment - Fundamentals of product certification } \\
\text { and guidelines for product certification schemes }\end{array}$ \\
\hline \multicolumn{3}{|c|}{ Conformity assessment procedures } \\
\hline Vocabulary & $\begin{array}{l}\text { ISO/IEC } \\
\underline{17000: 2004} \\
\end{array}$ & Conformity assessment - Vocabulary and general principles \\
\hline Management systems & $\frac{\underline{\text { ISO/PAS }}}{\underline{17005: 2008}}$ & $\begin{array}{l}\text { Conformity assessment - Use of management systems - } \\
\text { principles and requirements }\end{array}$ \\
\hline Management systems & $\begin{array}{l}\text { ISO/IEC } \\
\text { Guide 53: } \\
\underline{2005}\end{array}$ & $\begin{array}{l}\text { Conformity assessment - Guidance on the use of an } \\
\text { organization's quality management system in product } \\
\text { certification }\end{array}$ \\
\hline
\end{tabular}




\begin{tabular}{|c|c|c|}
\hline Topic & Standard & Title \\
\hline Audit reports & $\begin{array}{l}\text { ISO/IEC TS } \\
17022: 2012 \\
\end{array}$ & $\begin{array}{l}\text { Conformity assessment }- \text { Requirements and recommendations } \\
\text { for content of a third-party audit report on management systems }\end{array}$ \\
\hline $\begin{array}{l}\text { Indications of } \\
\text { conformity }\end{array}$ & $\begin{array}{l}\text { ISO/IEC } \\
\text { Guide } \\
\underline{23: 1982} \\
\end{array}$ & $\begin{array}{l}\text { Methods of indicating conformity with standards for third-party } \\
\text { certification systems }\end{array}$ \\
\hline Marks of conformity & $\begin{array}{l}\text { ISO/IEC } \\
\underline{17030: 2003} \\
\end{array}$ & $\begin{array}{l}\text { Conformity assessment - General requirements for third-party } \\
\text { marks of conformity }\end{array}$ \\
\hline $\begin{array}{l}\text { Declaration of } \\
\text { conformity }\end{array}$ & $\frac{\frac{1 \mathrm{SO} / \mathrm{IEC}}{17050-}}{\frac{1: 2004}{1: 200}}$ & $\begin{array}{l}\text { Conformity assessment }- \text { Supplier's declaration of conformity - } \\
\text { Part 1: General requirements }\end{array}$ \\
\hline $\begin{array}{l}\text { Supporting } \\
\text { documentation }\end{array}$ & $\begin{array}{l}\frac{\text { ISO/IEC }}{17050-} \\
\frac{2: 2004}{\underline{1}}\end{array}$ & $\begin{array}{l}\text { Conformity assessment - Supplier's declaration of conformity - } \\
\text { Part 2: Supporting documentation }\end{array}$ \\
\hline $\begin{array}{l}\text { Mutual recognition of } \\
\text { results }\end{array}$ & $\begin{array}{l}\text { ISO/IEC } \\
\text { Guide } \\
\underline{68: 2002}\end{array}$ & $\begin{array}{l}\text { Arrangements for the recognition and acceptance of conformity } \\
\text { assessment results }\end{array}$ \\
\hline Information disclosure & $\underline{1 \mathrm{SO} / \mathrm{PAS}}$ & $\begin{array}{l}\text { Conformity assessment - Disclosure of information - principles } \\
\text { and requirements }\end{array}$ \\
\hline Complaints and appeals & $\underline{1 \text { ISO/PAS }}$ & $\begin{array}{l}\text { Conformity assessment - Complaints and appeals - principles } \\
\text { and requirements }\end{array}$ \\
\hline \multicolumn{3}{|l|}{ Enforcement } \\
\hline Corrective actions & $\begin{array}{l}\frac{\text { ISO }}{\text { Guide }} \\
\underline{27: 1983} \\
\end{array}$ & $\begin{array}{l}\text { Guidelines for corrective action to be taken by a certification body } \\
\text { in the event of misuse of its mark of conformity }\end{array}$ \\
\hline \multicolumn{3}{|c|}{ Conformity assessment standards } \\
\hline $\begin{array}{l}\text { Conformity assessment } \\
\text { standards }\end{array}$ & $\begin{array}{l}\underline{\text { ISO/IEC }} \\
\underline{17007: 2009}\end{array}$ & $\begin{array}{l}\text { Conformity assessment - Guidance for drafting normative } \\
\text { documents suitable for use for conformity assessment }\end{array}$ \\
\hline
\end{tabular}

Source: ISO (2013b) 
Table B-3 ISO/ IEC 17067 Example Certification Programs

\begin{tabular}{|c|c|c|c|c|c|c|c|c|c|}
\hline \multicolumn{2}{|r|}{$\begin{array}{c}\text { Conformity assessment functions and activities a within } \\
\text { product certification schemes }\end{array}$} & \multicolumn{8}{|c|}{$\begin{array}{l}\text { Type of product certification } \\
\text { schemes }^{\text {b }}\end{array}$} \\
\hline & & $1 \mathbf{a}$ & $1 \mathbf{b}$ & 2 & 3 & 4 & 5 & 6 & $N^{c, d}$ \\
\hline $\mathbf{I}$ & $\begin{array}{l}\text { Selection, including planning and preparation activities, } \\
\text { specification of requirements, e.g., normative documents, and } \\
\text { sampling, as applicable }\end{array}$ & $\mathrm{X}$ & $X$ & $x$ & $X$ & $\mathrm{X}$ & $\mathrm{X}$ & $\mathrm{x}$ & $\mathrm{x}$ \\
\hline II & $\begin{array}{l}\text { Determination of characteristics, as applicable, by: } \\
\text { a) Testing } \\
\text { b) Inspection } \\
\text { c) Design appraisal } \\
\text { d) Assessment of services or processes } \\
\text { e) Other determination activities, e.g. verification }\end{array}$ & $X$ & $X$ & $X$ & $X$ & $X$ & $X$ & $\mathrm{x}$ & $x$ \\
\hline III & $\begin{array}{l}\text { Review, includes examining the evidence of conformity } \\
\text { obtained during the determination stage to establish whether } \\
\text { the specified requirements have been met }\end{array}$ & $X$ & $X$ & $X$ & $X$ & $X$ & $X$ & $\mathrm{x}$ & $X$ \\
\hline IV & $\begin{array}{l}\text { Decision on certification includes granting, maintaining } \\
\text { extending, reducing, suspending, and withdrawing } \\
\text { certification }\end{array}$ & $\mathrm{X}$ & $X$ & $x$ & $X$ & $X$ & $X$ & $X$ & $\mathrm{x}$ \\
\hline \multirow[t]{5}{*}{$\mathbf{v}$} & Attestation and licensing includes; & \multicolumn{8}{|c|}{, } \\
\hline & $\begin{array}{l}\text { a) Issuing a certificate of conformity or other statement of } \\
\text { conformity (attesting) }\end{array}$ & $X$ & $\mathrm{x}$ & $x$ & $x$ & $x$ & $x$ & $x$ & $\mathrm{X}$ \\
\hline & $\begin{array}{l}\text { b) Granting the right to use certificates or other } \\
\text { statements of conformity }\end{array}$ & $\mathrm{x}$ & $X$ & $x$ & $x$ & $x$ & $X$ & $x$ & \\
\hline & $\begin{array}{l}\text { c) Issuing a certificate of conformity for a batch or } \\
\text { products }\end{array}$ & & $\mathrm{x}$ & & & & & & \\
\hline & $\begin{array}{l}\text { d) Granting the right to use marks of conformity } \\
\text { (licensing) is based on surveillance (IV) or certification } \\
\text { of batch }\end{array}$ & & $X$ & $x$ & $x$ & $x$ & $x$ & $x$ & \\
\hline \multirow[t]{5}{*}{ VI } & Surveillance, as applicable by: & & & & & & & & \\
\hline & a) Testing or inspection of samples from the open market & & & $x$ & & $x$ & $x$ & & \\
\hline & b) Testing or inspection of samples from the factory & & & & $x$ & $x$ & $X$ & & \\
\hline & $\begin{array}{l}\text { c) Assessment of the production, the delivery of the } \\
\text { service, or the operation of the process }\end{array}$ & & & & $x$ & $x$ & $x$ & $x$ & \\
\hline & $\begin{array}{l}\text { d) Management system audits combined with random tests } \\
\text { or inspections }\end{array}$ & & & & & & $x$ & $x$ & \\
\hline
\end{tabular}

a. Where applicable, the activities can be coupled with initial audit and surveillance audit of the applicant's management system (an example is given in ISO/IEC Guide 53) or initial assessment of the production process. The order in which the assessments are performed may vary and will be defined within the scheme

b. An often used and well-tried model for a product certification scheme is describes in ISO/IEC guide 28; it is a product certification scheme corresponding to scheme type $\mathrm{V}$

c. A product certification scheme includes at least the activities I, II, III, IV and V

d. The symbol $\mathrm{N}$ has been added to show an undefined number of possible other schemes, which can be based on different activities. 
Table C-1 Sample PPE Conformity Assessment Programs in the United States

\begin{tabular}{|c|c|}
\hline Product Category & CA Program Owner(s) \\
\hline Arc flash protective clothing & $\begin{array}{l}\text { National Fire Protection Association } \\
\text { http://www.nfpa.org/ }\end{array}$ \\
\hline Ballistic body armor & $\begin{array}{l}\text { National Institute of Justice } \\
\text { https://www.nij.gov/topics/technology/body- } \\
\text { armor/pages/welcome.aspx }\end{array}$ \\
\hline Eye and face protection & $\begin{array}{l}\text { Safety Equipment Institute, http://www. seinet.org/ } \\
\text { Underwriters Laboratories, http://www.ul.com/aboutul/ } \\
\text { Canadian Standards Association (CSA) Group } \\
\text { https://www.ccohs.ca/legislation/csa.html }\end{array}$ \\
\hline Life safety ropes & $\begin{array}{l}\text { National Fire Protection Association } \\
\text { http://www.nfpa.org/ }\end{array}$ \\
\hline Head protection, hard hats & $\begin{array}{l}\text { Safety Equipment Institute, http://www.seinet.org/ } \\
\text { Underwriters Laboratories, http://www.ul.com/aboutul/ } \\
\text { Canadian Standards Association (CSA) Group, } \\
\text { https://www.ccohs.ca/legislation/csa.html } \\
\text { Snell Memorial Foundation, http://www.smf.org/ }\end{array}$ \\
\hline $\begin{array}{l}\text { Healthcare worker gowns, gloves, surgical masks, } \\
\text { and other medical devices }\end{array}$ & $\begin{array}{l}\text { U.S. Food and Drug Administration } \\
\text { https://www.fda.gov/ }\end{array}$ \\
\hline High visibility safety apparel and headwear & $\begin{array}{l}\text { U.S. Department of Transportation } \\
\text { https://www.transportation.gov/ }\end{array}$ \\
\hline Personal flotation devices & $\begin{array}{l}\text { U.S. Coast Guard } \\
\text { https://www.uscg.mil/hq/cg5/cg5214/pfd-lights.asp }\end{array}$ \\
\hline Protective footwear & $\begin{array}{l}\text { Safety Equipment Institute, Canadian Standards } \\
\text { Association (CSA) Group } \\
\text { http://www.seinet.org/ }\end{array}$ \\
\hline $\begin{array}{l}\text { Fire and emergency services protective clothing } \\
\text { and equipment }\end{array}$ & $\begin{array}{l}\text { National Fire Protection Association } \\
\text { http://www.nfpa.org/ }\end{array}$ \\
\hline Respirators & $\begin{array}{l}\text { National Institute for Occupational Safety and Health } \\
\text { https://www.cdc.gov/niosh/npptl/default.html }\end{array}$ \\
\hline Mining equipment and instrumentation & $\begin{array}{l}\text { Mine Safety and Health Administration } \\
\text { https://www.msha.gov/about/program- } \\
\text { areas/technical-support/approval-and-certification- } \\
\text { center }\end{array}$ \\
\hline
\end{tabular}

This list represents a sample of programs and should not be considered exhaustive. 
This Framework Checklist for CA program owners elaborates on the risk management system model introduced in Figure 1. The first three concepts of the checklist are activities that provide input into CA program decisions and are not necessarily performed by CA owner/operators. The last two concepts are primary activities of CA and should be directly addressed with the authority of the program owner and input from concepts one through three. The questions are intended to help program owners arrive at decisions that help ensure programs are tailored according to the potential risk of a non-conforming products and provide confidence with respect to product conformity to standards. This checklist is meant to assist in the process of developing appropriate CA programs, not the sole means of assuring adequacy. Along with relevant CA standards and technical guidance, this document can help increase confidence that a PPE CA program will perform according to desired outcomes.

Table D-1 Checklist for Application of PPE Conformity Assessment Framework

\begin{tabular}{|c|c|}
\hline $\begin{array}{c}\text { Steps } \\
\text { (Concepts) }\end{array}$ & Component Checklist Questions \\
\hline $\begin{array}{c}\text { Step 1: } \\
\text { Identify } \\
\text { hazards and } \\
\text { define risk to } \\
\text { workers }\end{array}$ & 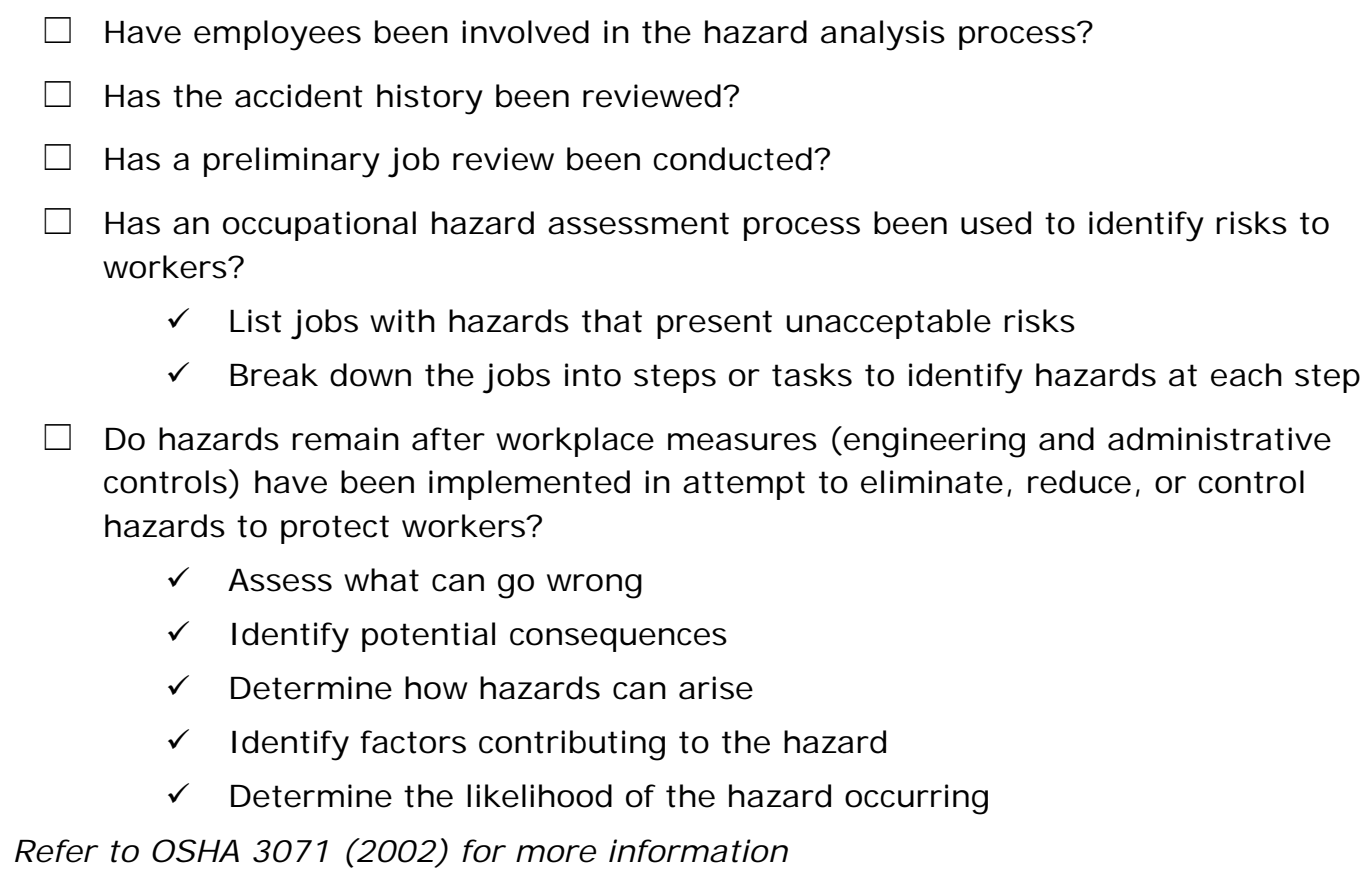 \\
\hline $\begin{array}{c}\text { Step 2: } \\
\text { Identify PPE } \\
\text { types needed } \\
\text { to address } \\
\text { hazards }\end{array}$ & $\begin{array}{l}\square \text { Has PPE been selected to address identified hazards that did not yield to } \\
\text { administrative or engineering controls? } \\
\square \text { Has a training program been established to train employees on the use of PPE? } \\
\checkmark \quad \text { What PPE is necessary? } \\
\checkmark \quad \text { When is PPE necessary? } \\
\checkmark \quad \text { How PPE will be inspected for wear or damage? } \\
\checkmark \quad \text { How does one properly put on and take off PPE? } \\
\checkmark \quad \text { What are the limitations of PPE? } \\
\checkmark \quad \text { How does one properly care for and store PPE? }\end{array}$ \\
\hline
\end{tabular}




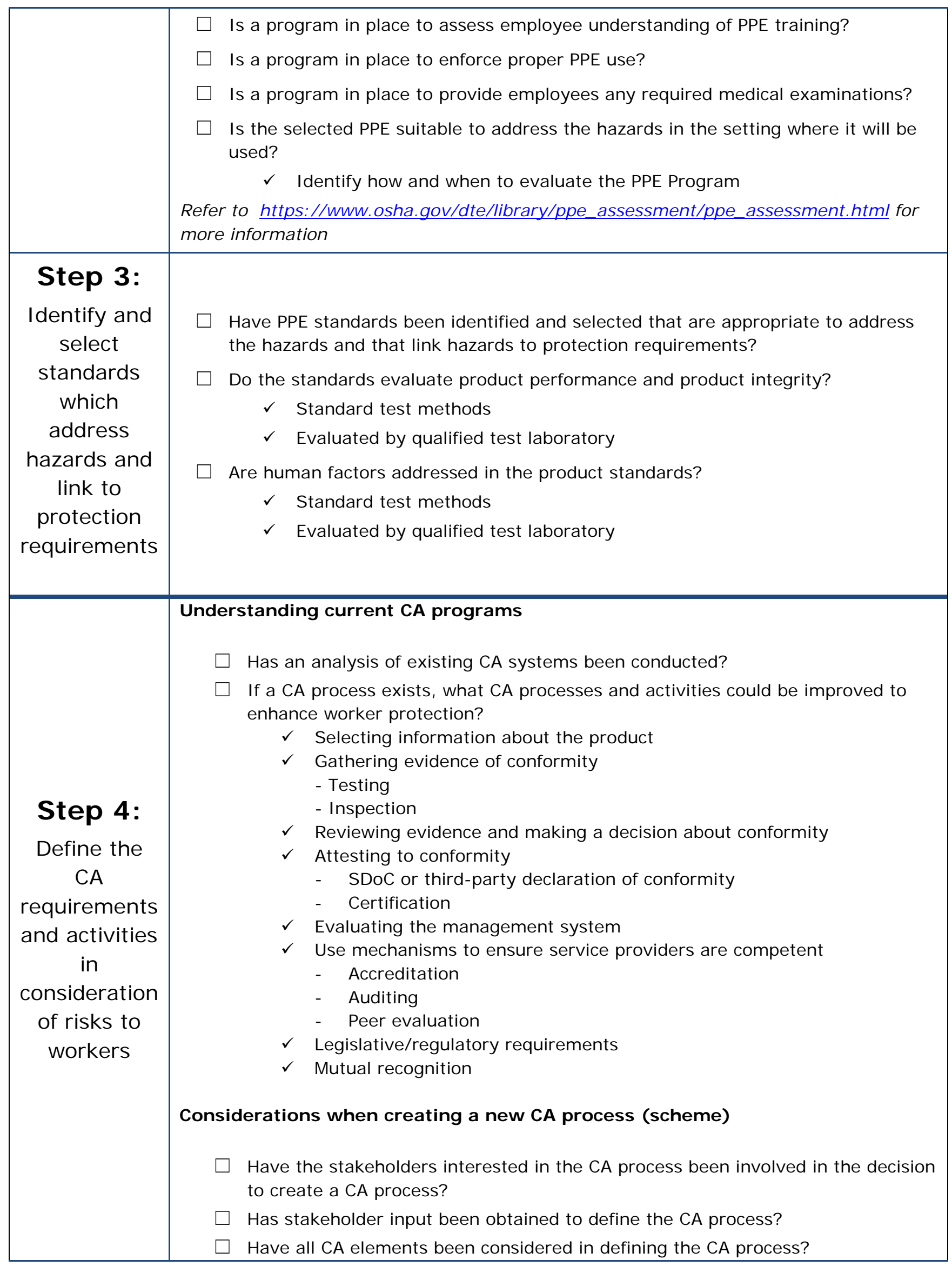


I ncorporating factors such as the risk of injury and illness associated with nonconformity

Have worksite hazards and risk to workers of non-conforming PPE been considered in selecting CA activities?

Have other factors been considered in selecting the appropriate level of rigor and independence of CA activities?

\section{Applying CA standards to identify the level of risk}

Have operational procedures been established for the selection, design and implementation of CA program requirements? This includes:

$\checkmark$ Selecting information about the product

- Identifying the specific and/or general requirements for products such as standard(s) or other document(s) to which conformity is to be assessed

- $\quad$ Selecting examples of the product to be assessed using statistical sampling techniques, if applicable.

$\checkmark$ Gathering evidence of conformity

- Testing to determine specified characteristics of the product [e.g. ISO 17025]

- Inspection of physical features of the product (e.g., visual examination of a physical item, measurement or testing of physical items, examination of design drawings or other specification documents) [e.g. ISO 17020]

- Auditing of supplier's quality system and records relating to the product. [e.g. ISO 9001]

Reviewing the evidence and making a decision about conformity

$\checkmark$ Review result of CA activities

$\checkmark$ Deciding whether the product conforms based on the evidence gathered.

Refer to ISO/IEC 17000

\section{Selecting the appropriate level of rigor and independence of CA activities}

Have worksite hazards and risk to workers of non-conforming PPE been considered in selecting CA activities?

Have other factors been considered in selecting the appropriate level of rigor and independence of CA activities?

Have operational procedures been established for the selection, design and implementation of CA program requirements? This includes:

$\checkmark$ Attesting to conformity 


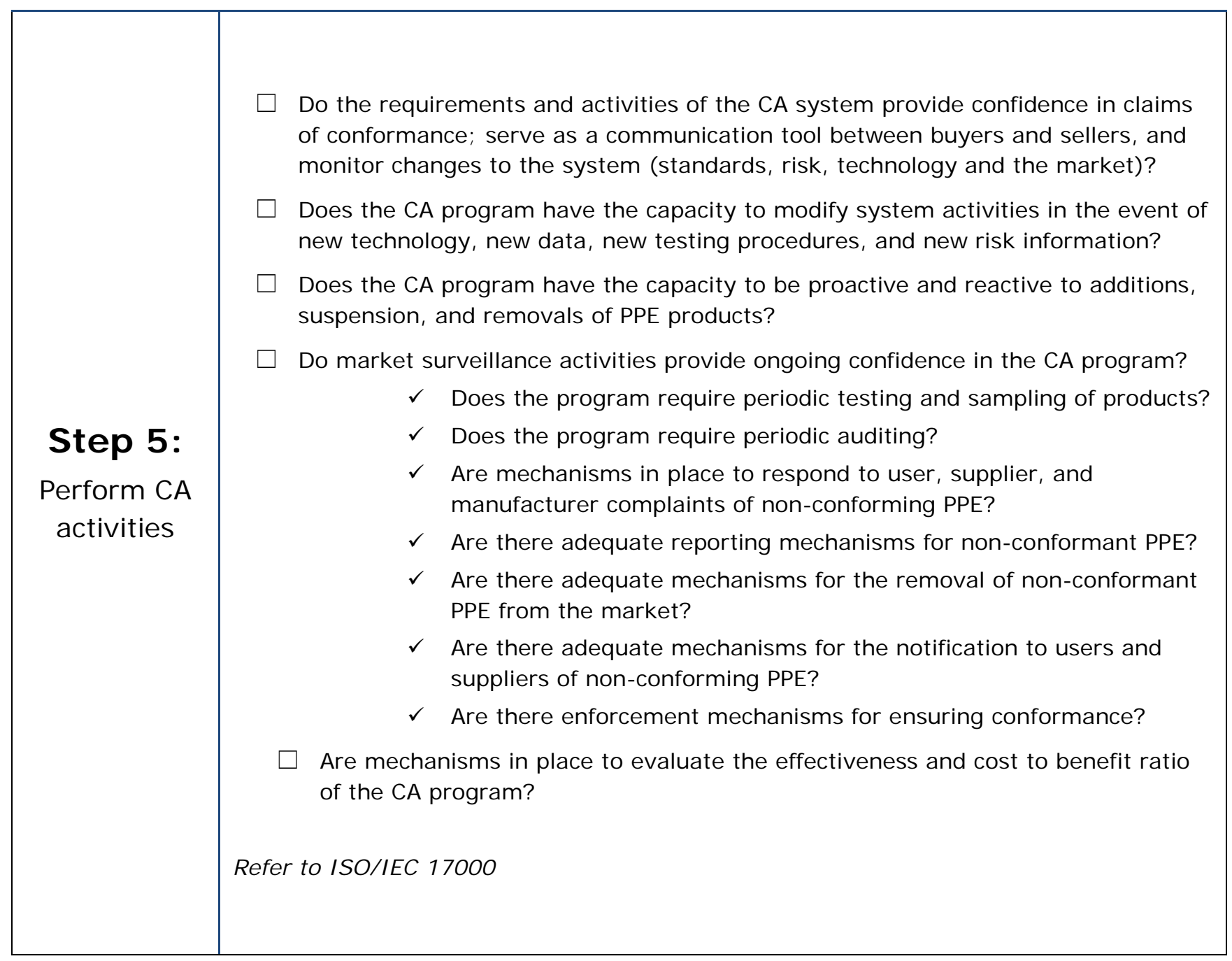




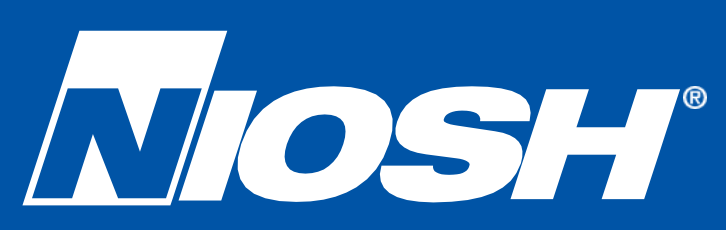

Delivering on the Nation's promise: Safety and health at work for all people through research and prevention

To receive NIOSH documents or more information about occupational safety and health topics, contact NIOSH:

1-800-CDC-INFO (1-800-232-4636) TTY: 1-888-232-6348

CDC-INFO: www.cdc.gov/info

or visit the NIOSH website at http://

www.cdc.gov/niosh.

For a monthly update on news at NIOSH, subscribe to NIOSH eNews by visiting www.cdc.gov/niosh/eNews.

DHHS (NIOSH) Publication No. 2018-102 